\title{
Deeply Rechargeable and Hydrogen-Evolution-Suppressing Zinc Anode in Alkaline Aqueous Electrolyte
}

\author{
Yamin Zhang ${ }^{1}$, Yutong $\mathrm{Wu}^{1}$, Wenqin You ${ }^{1}$, Mengkun Tian ${ }^{2}$, Po-Wei Huang ${ }^{1}$, Yifan \\ Zhang ${ }^{3}$, Zhijian $\mathrm{Sun}^{4}$, Yao Ma ${ }^{1}$, Tianqi $\mathrm{Hao}^{1}$, Nian $\mathrm{Liu}^{1, *}$
}

${ }^{1}$ School of Chemical and Biomolecular Engineering, Georgia Institute of Technology, Atlanta, Georgia 30332, United States

${ }^{2}$ The Institute for Electronics and Nanotechnology, Georgia Institute of Technology, Atlanta, Georgia 30332, United States

${ }^{3}$ School of Chemistry \& Biochemistry, Georgia Institute of Technology, Atlanta, Georgia 30332, United States

${ }^{4}$ School of Materials Science and Engineering, Georgia Institute of Technology, Atlanta, Georgia 30332, United States

*Correspondence: nian.liu@chbe.gatech.edu 


\section{Materials and Methods}

\section{Synthesis of the uncoated $\mathrm{ZnO}$ nanorod anode}

$\mathrm{ZnO}$ nanorods were grown on carbon papers $\left(8.4 \mathrm{mg} / \mathrm{cm}^{2}\right)$ by a hydrothermal method. Carbon paper (Fuel Cell Store) was first heated in air at $500{ }^{\circ} \mathrm{C}$ for $1 \mathrm{~h}$ to increase its wettability. Then, the carbon paper was soaked in $0.1 \mathrm{M} \mathrm{KMnO}_{4}$ (Sigma Aldrich) aqueous solution for $1 \mathrm{~h}$ to form a seed layer. The $\mathrm{ZnO}$ precursor solution is prepared by mixing $50 \mathrm{~mL}$ zinc nitrate hexahydrate (30 mM, Alfa Aesar), $50 \mathrm{~mL}$ hexamethylenetetramine (30 mM, Sigma Aldrich), and ammonia (28.0-30.0\% $\mathrm{NH}_{3}$ basis, Sigma Aldrich). The seeded carbon paper was placed in the above solution ${ }^{1}$, followed by heating in an oven at $90{ }^{\circ} \mathrm{C}$ for a certain time. After DI- $\mathrm{H}_{2} \mathrm{O}$ washing and drying at $80^{\circ} \mathrm{C}$ for $3 \mathrm{~h}$, the white-colored product on carbon paper was obtained. Different mass loadings $\left(0.5 \sim 5.5 \mathrm{mg} / \mathrm{cm}^{2}\right)$ of $\mathrm{ZnO}$ nanorods on carbon paper were achieved by adjusting reaction conditions, as summarized in Table S1. Specifically, the "Repeat" column means that the $\mathrm{ZnO}$ nanorods-loaded carbon paper from the first reaction was put into a new precursor solution to repeat the reaction.

Table S1. Experiment conditions for different mass loadings of $\mathrm{ZnO}$ nanorods.

\begin{tabular}{|c|c|c|c|c|}
\hline Mass loading & $\begin{array}{c}\text { Carbon paper } \\
\text { area per batch }\end{array}$ & $\mathrm{NH}_{3}$ quantity & $\begin{array}{c}\text { Total hydrothermal } \\
\text { time }\end{array}$ & Repeat \\
\hline $0.5 \mathrm{mg} / \mathrm{cm}^{2}$ & $2 \times(2.1 * 6) \mathrm{cm}^{2}$ & $2 \mathrm{~mL}$ & $13 \mathrm{~h}$ & No \\
\hline $0.9 \mathrm{mg} / \mathrm{cm}^{2}$ & $1 \times(2.1 * 6) \mathrm{cm}^{2}$ & $4 \mathrm{~mL}$ & $22 \mathrm{~h}$ & No \\
\hline $5.5 \mathrm{mg} / \mathrm{cm}^{2}$ & $1 \times(2.1 * 6) \mathrm{cm}^{2}$ & $4 \mathrm{~mL}$ & $2 * 20=40 \mathrm{~h}$ & Once \\
\hline
\end{tabular}

\section{Synthesis of the HER suppressing sealed nanosized (HSSN) zinc anode}

The HSSN zinc anode with the $\mathrm{ZnO}$ core/ $/ \mathrm{TiO}_{2}$ shell structure was synthesized using a solution method.

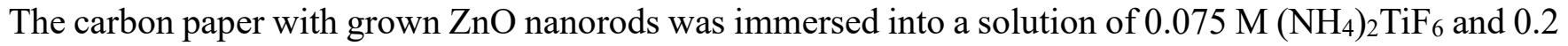
$\mathrm{M} \mathrm{H}_{3} \mathrm{BO}_{3}$ for $10 \mathrm{~min}$ at room temperature ${ }^{2}$. A layer of $\sim 30 \mathrm{~nm}$ thick $\mathrm{TiO}_{2}$ was deposited.

\section{Synthesis of the $\mathrm{ZnO} @ \mathrm{TiN}_{\mathrm{x}} \mathrm{O}_{\mathrm{y}}$ anode}

To get the $\mathrm{ZnO} @ \mathrm{TiN}_{\mathrm{x}} \mathrm{O}_{\mathrm{y}}$ anode, TiN was deposited onto the uncoated $\mathrm{ZnO}$ nanorod anode through atomic layer deposition (ALD). ALD was conducted in Cambridge FIJI Plasma ALD system. The detailed ALD recipe is shown in Fig. S14. The precursors of TiN were TDMAT and $\mathrm{N}_{2}$. During TiN ALD process, the recipe was run 200 cycles ( $1 \AA$ per cycle) at $250{ }^{\circ} \mathrm{C}$. Then, when $\mathrm{ZnO} @$ TiN nanorods were exposed to air, the TiN was partially oxidized to $\mathrm{TiN}_{\mathrm{x}} \mathrm{O}_{\mathrm{y}}$ (Fig. S11).

\section{Sheet resistance measurement of $\mathrm{TiN}_{\mathrm{x}} \mathrm{O}_{\mathrm{y}}$ and $\mathrm{TiO}_{2}$ coatings using a four-point probe system}

To measure the sheet resistance of $\mathrm{TiN}_{\mathrm{x}} \mathrm{O}_{\mathrm{y}}$ and $\mathrm{TiO}_{2}$ coatings, $\mathrm{TiN}_{\mathrm{x}} \mathrm{O}_{\mathrm{y}}$ and $\mathrm{TiO}_{2}$ are deposited onto glass slides, respectively. The glass slides were cleaned by sonication in acetone/ethanol, followed by ultraviolet-ozone (UVO) treatment. $\mathrm{TiN}_{\mathrm{x}} \mathrm{O}_{\mathrm{y}}$ was obtained through an $\mathrm{ALD}$ of $\mathrm{TiN}$ on the glass slides 
followed by an oxidation step in air. The precursors of TiN were TDMAT and $\mathrm{N}_{2}$. The detailed ALD recipe is shown in Fig. S14. During ALD process, the recipe was run 400 cycles $(1 \AA$ per cycle $)$ at $250{ }^{\circ} \mathrm{C}$. A layer of $\sim 1 \mu \mathrm{m}$ thick $\mathrm{TiO}_{2}$ was deposited on the glass slides by immersing the glass slides in a solution of $0.1 \mathrm{M}\left(\mathrm{NH}_{4}\right)_{2} \mathrm{TiF}_{6}+0.2 \mathrm{M} \mathrm{H}_{3} \mathrm{BO}_{3}$ for $11 \mathrm{~h}$ at $25^{\circ} \mathrm{C}^{2}$. The sheet resistance was measured using a four-point probe measurement system (2000 multimeter, Keithley).

\section{Material Characterization and Measurements}

The morphological and compositional analyses were carried out using scanning electron microscopy (SEM, Hitachi SU 8230), transmission electron microscopy (TEM, Hitachi HT7700, FEI Tecnai F30, and JEOL 100 CX-II), and scanning transmission electron microscopy (STEM, Hitachi HD-2700). The X-ray diffraction patterns (XRD, Panalytical XPert PRO Alpha-1) were carried out with Cu K-Alpha radiation. The X-ray photoelectron spectroscopy (XPS) was measured with Thermo Scientific K-Alpha system. The specific Brunauer-Emmett-Teller surface areas and pore size distribution were determined by physisorption (BELSORP-max, MicrotracBEL Corp.). The dissolved Zn concentration of samples in $4 \mathrm{M}$ $\mathrm{KOH}$ electrolyte was measured with an inductively coupled plasma (ICP) measurement. Cyclic voltammetry, linear sweep voltammetry, and electrochemical impedance spectroscopy were conducted using a VSP system (BioLogic). Battery cycling tests were carried out using LANHE operating in galvanostatic mode.

In the battery-gas chromatography quantitative analysis measurement, the airtight battery system (Fig. S1) was connected to a gas chromatography (MG\#5, SRI Instruments). The system was purged with Ar before the measurement. The stainless-steel rod was used as the anode. ZnO-saturated 4M KOH (Sigma Aldrich) was used as the electrolyte. A $4 \mathrm{~cm}^{2}$ cathode from a commercial Ni-Zn AA battery (PowerGenix), which is a mixture of $\mathrm{NiOOH}\left(\sim 8 \mathrm{mAh} / \mathrm{cm}^{2}\right) / \mathrm{Ni}(\mathrm{OH})_{2}\left(\sim 32 \mathrm{mAh} / \mathrm{cm}^{2}\right)$, was harvested to pair with the anode. The battery was charged at $20 \mathrm{~mA}$ for $15 \mathrm{~min}$ and then fully discharged $(20 \mathrm{~mA})$ to $0.8 \mathrm{~V}$ for 1 cycle. Then $\mathrm{H}_{2}$ measurements were conducted using the thermal conductivity detector. Ar was the carrier gas for gas chromatography. The capacity loss on the $\mathrm{Zn}$ anode is almost fully caused by HER (99.47\%).

$$
\text { Capacity loss }=\text { Charge capacity }- \text { Discharge capacity }=\text { Capacity }(\text { HER })+\text { Capacity (Other) }
$$

\section{Electrochemistry}

The zinc anodes were cut to round disks with diameter of $1 \mathrm{~cm}$. Cathodes from commercial Ni-Zn AA batteries (PowerGenix), which is a mixture of $\mathrm{NiOOH}\left(\sim 8 \mathrm{mAh} / \mathrm{cm}^{2}\right) / \mathrm{Ni}(\mathrm{OH})_{2}\left(\sim 32 \mathrm{mAh} / \mathrm{cm}^{2}\right)$, were harvested to pair with the anodes.

Coin cell: CR2032 cases (MTI Corporation) were used to make coin cells. The aqueous electrolyte consists of $4 \mathrm{M} \mathrm{KOH}$ (Sigma Aldrich, 99.99\%), $2 \mathrm{M} \mathrm{KF}$ (Alfa Aesar, 99.99\%) and $2 \mathrm{M} \mathrm{K}_{2} \mathrm{CO}_{3}$ (Alfa Aesar, $99.997 \%)^{3} .25 \mu \mathrm{L}$ electrolyte was used. Glass fiber (GE Healthcare, Whatman ${ }^{\mathrm{TM}} 10370003$ ) was used as the separator. 
Pouch cell: Pouch-type batteries (Fig. S20) were assembled using Ampac's SealPAK. The mass loading of active material $(\mathrm{ZnO})$ on the anode is $1.5 \mathrm{mg} / \mathrm{cm}^{2}$. The aqueous electrolyte consists of $4 \mathrm{M} \mathrm{KOH}$ (Sigma Aldrich, 99.99\%), 2 M KF (Alfa Aesar, 99.99\%) and $2 \mathrm{M} \mathrm{K}_{2} \mathrm{CO}_{3}$ (Alfa Aesar, 99.997\%) with saturated ZnO. $100 \mu \mathrm{L}$ electrolyte was used. Glass fiber (GE Healthcare, Whatman ${ }^{\mathrm{TM}}$ 10370003) was used as the separator. Ti wires were used as electrode terminals. Cells are galvanostatically cycled at a charge rate of $1 \mathrm{C}$ and a discharge rate of $5 \mathrm{C}$ between 1.4 and $1.9 \mathrm{~V}$. For anodes cycled at $100 \% \mathrm{DOD}$, the anodes were activated by being pre-cycled in pouch cells for 6 cycles. The charge capacity limit cut-off is $658 \mathrm{mAh} / \mathrm{g}$ (theoretical specific capacity of $\mathrm{ZnO}$ ). For anodes cycled at $40 \%$ DOD, the anodes were activated by being pre-cycled with $100 \%$ active material utilization for 1 cycle and then being fully charged.

Beaker cell: In beaker-type batteries, the mass loading of active material $(\mathrm{ZnO})$ on the anode is $1.6 \mathrm{mg} / \mathrm{cm}^{2}$. $10 \mathrm{~mL}$ ZnO-saturated 4M KOH (Sigma Aldrich) was used as the electrolyte. Cells are galvanostatically cycled at $100 \%$ DOD at a charge rate of $1 \mathrm{C}$ and a discharge rate of $5 \mathrm{C}$ between 1.4 and $1.9 \mathrm{~V}$. The anodes were activated by being pre-cycled in beaker cells for 50 cycles. The charge capacity limit cut-off is 658 $\mathrm{mAh} / \mathrm{g}$. Ag wire was used as anode terminal. Stainless steel wire was used as cathode terminal.

The theoretical specific capacity of $\mathrm{ZnO}$ is $658 \mathrm{mAh} / \mathrm{g}$. This was calculated by

$$
C_{T}\left(m A h g^{-1}\right)=\frac{1}{M W} * \frac{n F}{3.6}
$$

where MW is the molar weight of active material, $\mathrm{n}$ is the number of electrons transferred in the relevant reaction, and $\mathrm{F}$ is the Faraday's constant. In this work, $\mathrm{MW}$ of $\mathrm{ZnO}=81.38 \mathrm{~g} / \mathrm{mol} ; \mathrm{n}=2 ; \mathrm{F}=96485 \mathrm{C} / \mathrm{mol}$.

The specific discharge capacity of the electrode was calculated by

$$
C=I t / m
$$

where $\mathrm{I}$ is the discharge current, $\mathrm{t}$ is the discharge time per cycle, and $\mathrm{m}$ is the mass of $\mathrm{ZnO}$.

A rate of $\mathrm{mC}$ corresponds to a full charge/discharge in $1 / \mathrm{m}$ hours.

Electrolyte-to-discharge-capacity (E/DC) ratio:

$$
\mathrm{E} / \mathrm{DC} \text { ratio }=\text { Volume of electrolyte } / \text { measured discharge capacity }
$$

The theoretical gravimetric capacity of $\mathrm{Zn}$ metal:

$$
C_{g}\left(m A h g^{-1}\right)=\frac{1}{M W_{Z n}} * \frac{n F}{3.6}=\frac{1}{65.38} * \frac{2 * 96485}{3.6}=820
$$

The theoretical volumetric capacity of $\mathrm{Zn}$ metal:

$$
C_{v}\left(m A h \mathrm{~cm}^{-3}\right)=C_{g} * \rho_{Z n}=5854
$$

where $\rho_{Z n}$ is the density of $Z n$ metal. $\rho_{Z n}=7.14 \mathrm{~g} \mathrm{~cm}^{-3}$.

The theoretical gravimetric energy density of Zn-air batteries (calculated based on the discharged state, 
$\mathrm{ZnO})$ :

$$
E_{g}\left(W h k^{-1}\right)=\frac{1}{M W_{Z n O}} * \frac{n F}{3.6} * V=\frac{1}{81.38} * \frac{2 * 96485}{3.6} * 1.66=1093
$$

where $V$ is the battery volatge. $V=1.66 \mathrm{~V}$.

The theoretical volumetric energy density of $\mathrm{Zn}$-air batteries:

$$
E_{v}\left(W h L^{-1}\right)=E_{g} * \rho_{Z n O}=6134
$$

where $\rho_{Z n O}$ is the density of $\mathrm{ZnO} . \rho_{Z n O}=5.61 \mathrm{~g} \mathrm{~cm}^{-3}$. 


\section{Simulation of hydrogen suppressing property}

Simulation based on force field model was conducted to investigate the hydrogen suppressing property of $\mathrm{TiO}_{2}$ and $\mathrm{TiN}_{\mathrm{x}} \mathrm{O}_{\mathrm{y}}$. The Monte Carlo and Least Squares techniques are used to minimize the energy. $\mathrm{Ti}_{5} \mathrm{O}_{10}$ cluster was used to represent amorphous $\mathrm{TiO}_{2}$. For $\mathrm{TiN}_{\mathrm{x}} \mathrm{O}_{\mathrm{y}}$, the overall atomic ratio of $\mathrm{O}$ to $\mathrm{N}(\mathrm{O} / \mathrm{N})$ was experimentally determined to be 6.66 as evidenced by XPS (Figure S11). From many possible structures of amorphous $\mathrm{TiN}_{\mathrm{x}} \mathrm{O}_{\mathrm{y}}$, we chose and built four representative models (denoted as $\operatorname{TiN}_{\mathrm{x}} \mathrm{O}_{\mathrm{y}}-\mathrm{n}, \mathrm{n}=1,2,3,4$ ) with $\mathrm{O} / \mathrm{N}$ atomic ratios of 9 and 4 to simulate the actual shell material. $\operatorname{Ti}_{5} \mathrm{O}_{9} \mathrm{~N}$ cluster $(\mathrm{O} / \mathrm{N}=9)$ for $\mathrm{TiN}_{\mathrm{x}} \mathrm{O}_{\mathrm{y}^{-}}$ 1 and $\mathrm{TiN}_{\mathrm{x}} \mathrm{O}_{\mathrm{y}}-2$, and $\mathrm{Ti}_{5} \mathrm{O}_{8} \mathrm{~N}_{2}$ cluster $(\mathrm{O} / \mathrm{N}=4)$ for $\mathrm{TiN}_{\mathrm{x}} \mathrm{O}_{\mathrm{y}}-3$ and $\mathrm{TiN}_{\mathrm{x}} \mathrm{O}_{\mathrm{y}}-4$ are built. $\Delta \mathrm{G}_{\mathrm{H}}{ }^{*}$ represents the free energy for $\mathrm{H}$ adsorption. In a three-state diagram, consisting of an initial $\mathrm{H}^{+}$state, an intermediate $\mathrm{H}^{*}$ state, and $1 / 2 \mathrm{H}_{2}$ as the final product, the material with higher $\left|\Delta \mathrm{G}_{\mathrm{H}}{ }^{*}\right|$ value possesses lower catalytic activity ${ }^{4,5}$ and thus better hydrogen suppressing capability. $\Delta \mathrm{G}_{\mathrm{H}}{ }^{*}$ was obtained by $\Delta G_{H^{*}}=\Delta E_{H}+$ $\Delta E_{Z P E}-T \Delta S_{H}$, where $\Delta E_{H}$ is the binding energy of $\mathrm{H}$ species, $\Delta E_{Z P E}$ and $\Delta S_{H}$ are the zero point energy change and entropy change of adsorption $\mathrm{H}$, respectively. The contribution of entropies and ZPE for $\Delta G_{H^{*}}$ were obtained according to literatures ${ }^{4,5}$, where finally $\Delta G_{H^{*}}=\Delta E_{H}+0.24 \mathrm{eV} . \Delta E_{H}$ was obtained by $\Delta E_{H}=E_{M-H}-E_{M}-1 / 2 \times E_{H_{2}} . E_{H_{2}}$ was calculated to be $-3.040 \mathrm{eV}$. The summary of these values is listed in Supplementary Table $\mathbf{S 2}$. 
Supplementary Table S2. Summary of simulated energy of clusters (M) and H adsorbed clusters (M$\mathrm{H})$, binding energy, and free energy.*

\begin{tabular}{|c|c|c|c|c|c|}
\hline M & $\mathrm{TiO}_{2}$ & $\mathrm{TiN}_{x} \mathrm{O}_{\mathrm{y}}-1$ & $\mathrm{TiN}_{x} \mathrm{O}_{\mathrm{y}}-2$ & $\mathrm{TiN}_{\mathrm{x}} \mathrm{O}_{\mathrm{y}}-3$ & $\mathrm{TiN}_{\mathrm{x}} \mathrm{O}_{\mathrm{y}-4}$ \\
\hline$E_{M}$ & $-12.282 \mathrm{eV}$ & $-14.865 \mathrm{eV}$ & $-14.378 \mathrm{eV}$ & $-18.086 \mathrm{eV}$ & $-18.058 \mathrm{eV}$ \\
\hline$E_{M-H}$ & $-13.547 \mathrm{eV}$ & $-16.382 \mathrm{eV}$ & $-16.125 \mathrm{eV}$ & $-19.498 \mathrm{eV}$ & $-19.792 \mathrm{eV}$ \\
\hline$\Delta E_{H}$ & $0.255 \mathrm{eV}$ & $0.003 \mathrm{eV}$ & $-0.227 \mathrm{eV}$ & $0.108 \mathrm{eV}$ & $-0.214 \mathrm{eV}$ \\
\hline$\Delta \mathrm{G}_{\mathrm{H}}{ }^{*}$ & $0.495 \mathrm{eV}$ & $0.243 \mathrm{eV}$ & $0.013 \mathrm{eV}$ & $0.348 \mathrm{eV}$ & $0.026 \mathrm{eV}$ \\
\hline
\end{tabular}

*Atoms in clusters: pink, $\mathrm{H}$; blue, $\mathrm{N}$; red, $\mathrm{O}$; green, Ti. 


\section{Summary and comparison of Coulombic efficiency}

Supplementary Table S3. Comparison of Coulombic efficiency of our HSSN anode with previously reported zinc-based anodes (100\% depth of discharge) in alkaline electrolytes.

\begin{tabular}{|c|c|}
\hline Anode material & Coulombic efficiency (\%) \\
\hline $\mathrm{Ca}(\mathrm{OH})_{2}$-coated $\mathrm{ZnO}^{6}$ & 29.10 \\
\hline $\mathrm{Sn}_{6} \mathrm{O}_{4}(\mathrm{OH})_{4}$-coated $\mathrm{ZnO}^{7}$ & 37.50 \\
\hline $\mathrm{ZnO}$ nanoplate ${ }^{8}$ & 69.15 \\
\hline Ag-modified $\mathrm{ZnO}^{9}$ & 71.43 \\
\hline $\mathrm{ZnAlSb}-\mathrm{LDH}^{10}$ & 78.10 \\
\hline $\mathrm{ZnO} / \mathrm{SnO}_{2}{ }^{11}$ & 84.62 \\
\hline $\mathrm{ZnO} @ \mathrm{RGO}^{12}$ & 85.00 \\
\hline $\mathrm{ZnO}$ microspheres ${ }^{13}$ & 86.63 \\
\hline ZnO@Ag@Polypyrrole ${ }^{14}$ & 89.00 \\
\hline $\operatorname{LDOs}^{15}$ & 89.42 \\
\hline $\mathrm{Ag} / \mathrm{ZnO}^{16}$ & 89.67 \\
\hline $\mathrm{IZO}^{17}$ & 91.04 \\
\hline $\mathrm{SnO}_{2} @ \mathrm{ZnO}^{18}$ & 91.19 \\
\hline Ag-LDH ${ }^{19}$ & 93.19 \\
\hline This work & 93.50 \\
\hline
\end{tabular}




\section{Summary and comparison of E/DC ratio and Coulombic efficiency}

Supplementary Table S4. Comparison of our HSSN anode with previously reported zinc-based anodes in aspects of electrolyte-to-discharge-capacity (E/DC) ratio and Coulombic efficiency in alkaline electrolyte. The depth of discharge of Anode No. 1 - Anode No. 22 are 100\%. The depth of discharge of Anode No. 0 is $40 \%$.

\begin{tabular}{|c|c|c|c|}
\hline Anode No. & Anode material & E/DC ratio $(\mathrm{mL} / \mathrm{mAh})$ & $\begin{array}{c}\text { Coulombic efficiency } \\
(\%)\end{array}$ \\
\hline 0 & $\mathrm{Zn}_{\text {sponge }} \mathrm{e}^{20}$ & 0.0062 & $\sim 100$ \\
\hline 1 & Backside-plating zinc ${ }^{21}$ & 34.09 & 92.0 \\
\hline 2 & $\mathrm{ZnO} @ \mathrm{C}^{22}$ & 0.29 & 58.8 \\
\hline 3 & $\mathrm{ZnO} @ \mathrm{TiN}_{\mathrm{x}} \mathrm{O}_{\mathrm{y}}{ }^{23}$ & 0.47 & 81.6 \\
\hline 4 & Zn-pome ${ }^{24}$ & 0.27 & 55.5 \\
\hline 5 & $\mathrm{ZnO}$ lasagna ${ }^{25}$ & 0.32 & 47.9 \\
\hline 6 & $\mathrm{ZnO}$ nanoparticle $\mathrm{e}^{26}$ & 0.06 & 67.1 \\
\hline 7 & $\mathrm{ZnO}$ particle ${ }^{26}$ & 0.05 & 72.7 \\
\hline 8 & $\mathrm{ZnO}$ nanorod $^{26}$ & 0.05 & 79.3 \\
\hline 9 & Calcium zincate en $^{27}$ & 0.10 & 77.5 \\
\hline 10 & $\mathrm{Zn} @ \mathrm{Bi}_{2} \mathrm{O}_{3}-\mathrm{CaO}-\mathrm{ZnO}$ glass $^{28}$ & 8.00 & 83.3 \\
\hline 11 & $\mathrm{IHCP}-\mathrm{ZnO} / \mathrm{C}^{29}$ & 0.10 & 60.8 \\
\hline 12 & Commercial $\mathrm{ZnO}^{30}$ & 0.58 & 85.5 \\
\hline 13 & TRIEN-ZnO ${ }^{30}$ & 0.59 & 84.5 \\
\hline 14 & $\mathrm{EN}-\mathrm{ZnO}{ }^{30}$ & 0.58 & 86.5 \\
\hline
\end{tabular}




\begin{tabular}{cccc}
\hline 15 & $\mathrm{DIEN} \mathrm{ZnO}^{30}$ & 0.53 & 93.7 \\
\hline 16 & $\mathrm{Cr}_{\mathrm{x}} \mathrm{ZnO}^{31}$ & 0.41 & 82.0 \\
\hline 17 & $\mathrm{Ni}_{\mathrm{x}} \mathrm{Zn}_{(1-\mathrm{x})} \mathrm{O}^{32}$ & 0.34 & 98.0 \\
\hline 18 & $\mathrm{Microcrystalline} \mathrm{ZnO}^{33}$ & 0.38 & 87.0 \\
\hline 19 & $\mathrm{Fe}_{0.01} \mathrm{ZnO}^{34}$ & 0.72 & 92.0 \\
\hline 20 & $\mathrm{ZnO}_{\mathrm{LiOH}}{ }^{35}$ & 0.36 & 93.0 \\
\hline 21 & $\mathrm{Mg}_{\mathrm{x}} \mathrm{Zn}_{1-\mathrm{x}} \mathrm{O}^{36}$ & 0.58 & 85.5 \\
\hline 22 & $\mathrm{This} \mathrm{work}^{20}$ & $\mathbf{0 . 1 4}$ & $\mathbf{9 3 . 5}$ \\
\hline
\end{tabular}


a

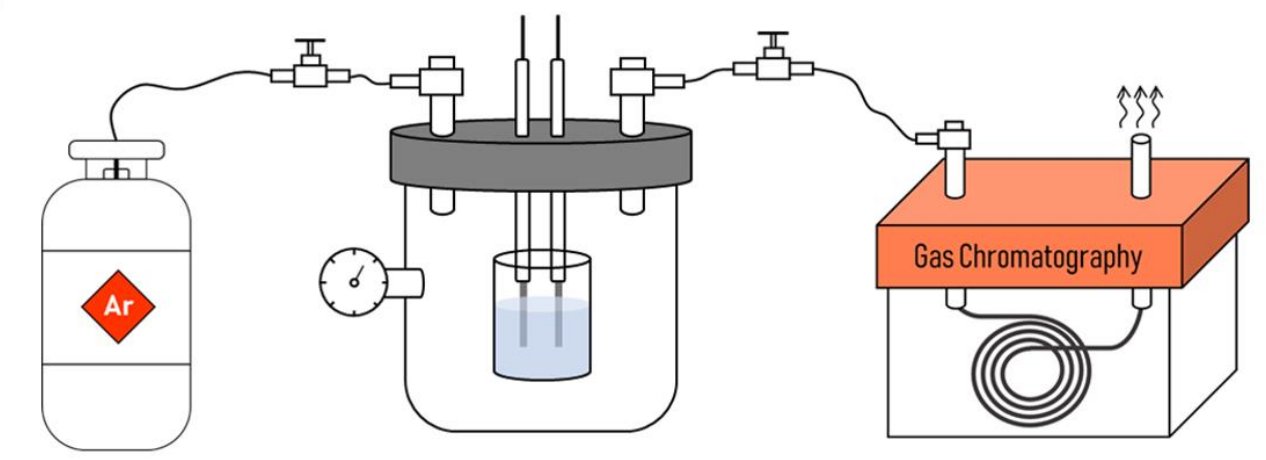

b
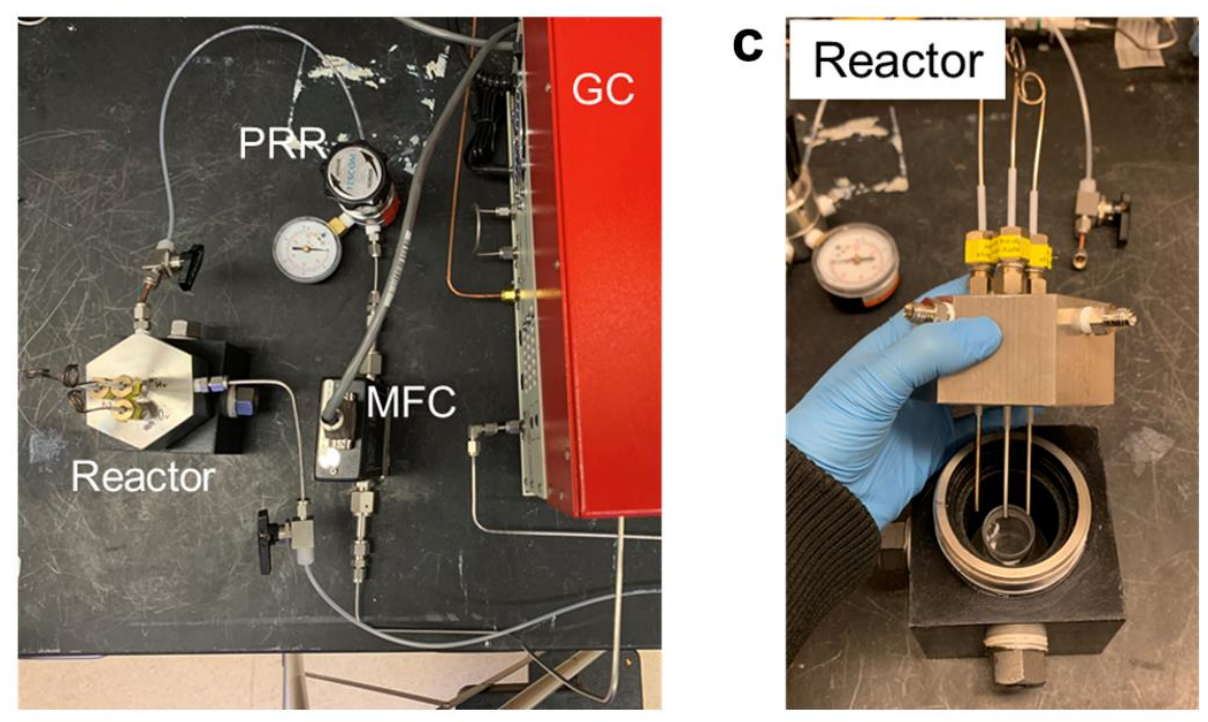

Figure S1. (a-c) Schematic diagram (a), experiment setup (b), and reactor design (c) of the battery-GC quantitative analysis method to quantitatively identify the influence of HER on Coulombic efficiency of zinc anodes. PRR: pressure reducing regulator; MFC: mass flow controller; GC: gas chromatography. 

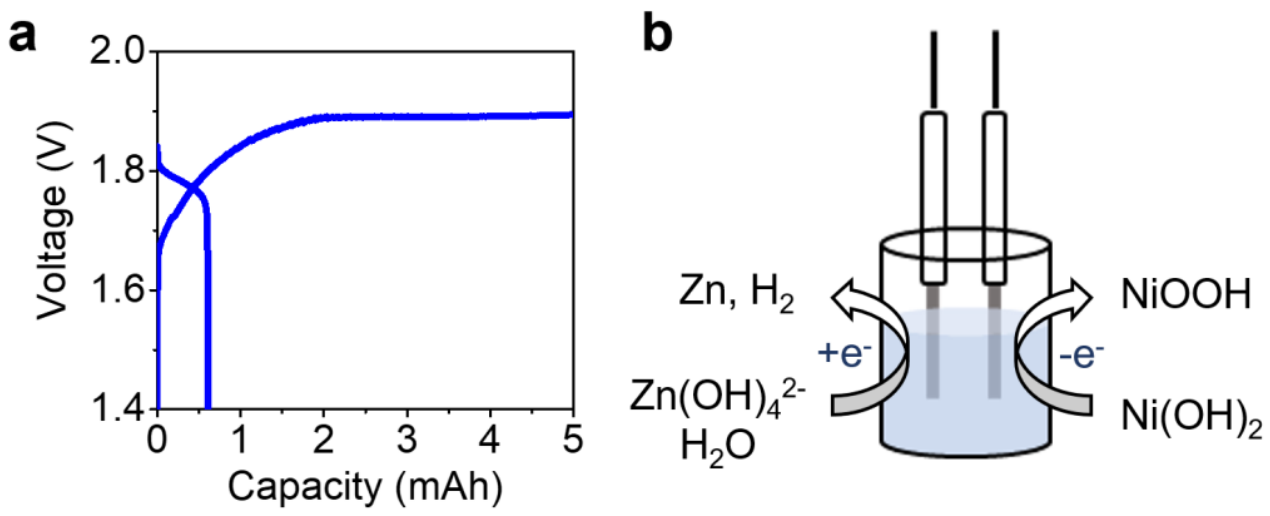

Figure S2. Electrode reactions happened during charging for $\mathrm{Zn}-\mathrm{Ni}$ battery system. 


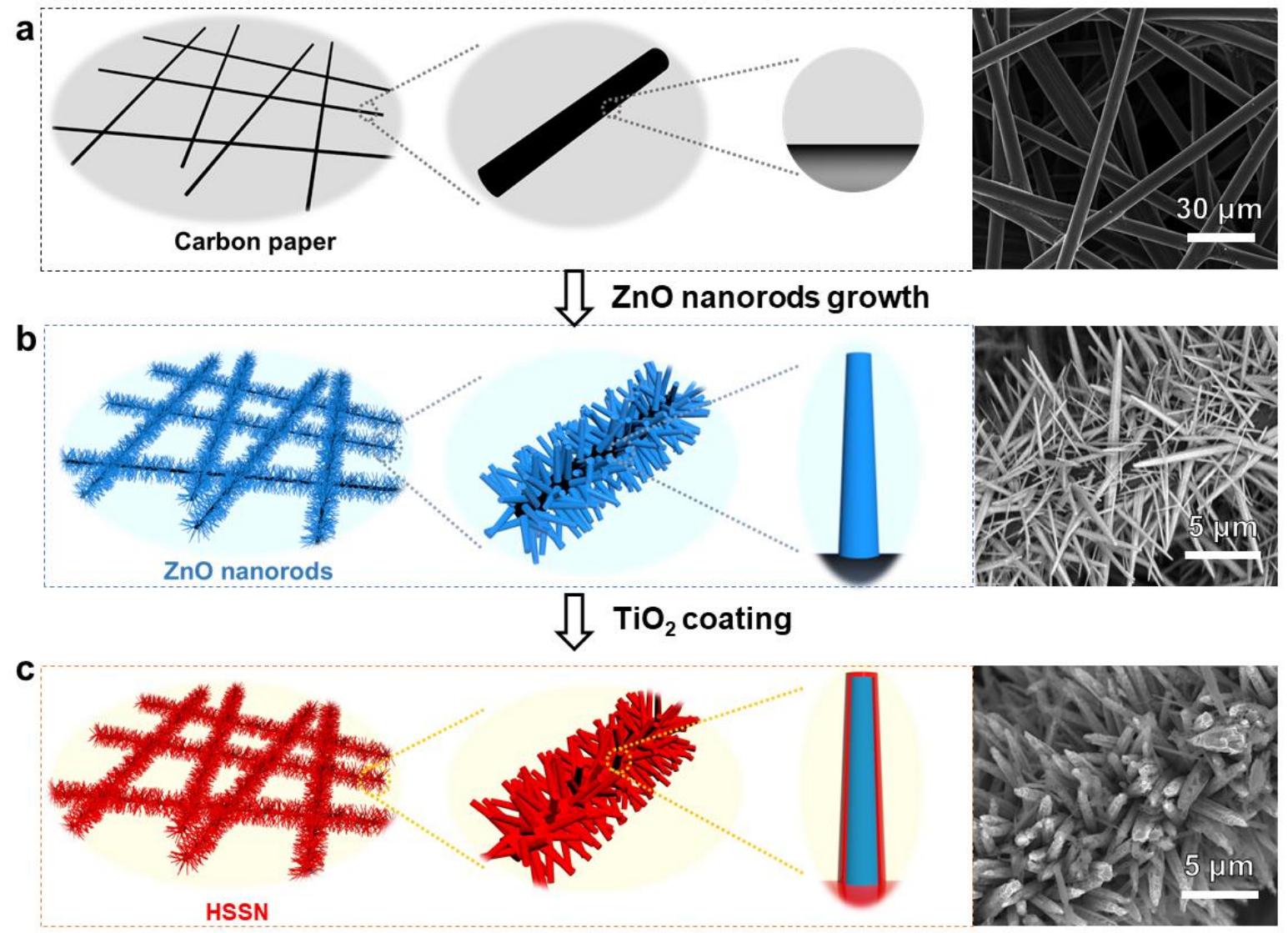

Figure S3. Fabrication of the HSSN anode. a,b,c, Schematic diagrams and SEM images of carbon paper (a), ZnO nanorod anode (b), and HSSN anode (c). 

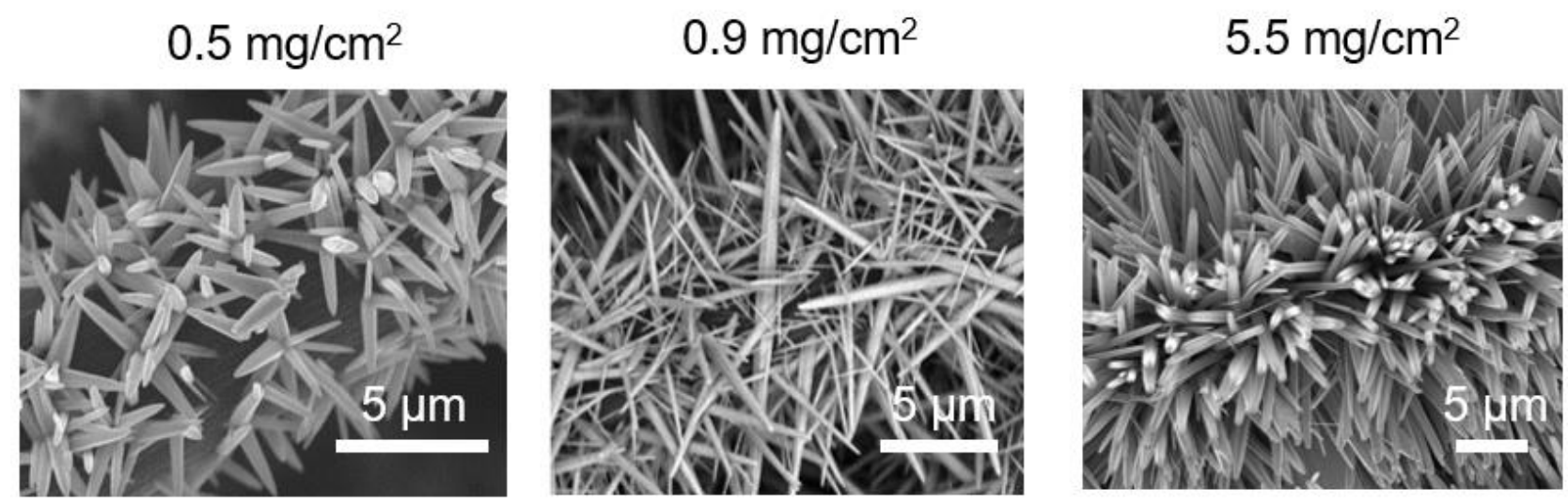

Figure S4. SEM images of uncoated $\mathrm{ZnO}$ nanorod anode with mass loading of $\mathrm{ZnO}$ nanorods ranges from $0.5 \mathrm{mg} / \mathrm{cm}^{2}$ to $5.5 \mathrm{mg} / \mathrm{cm}^{2}$. 
a

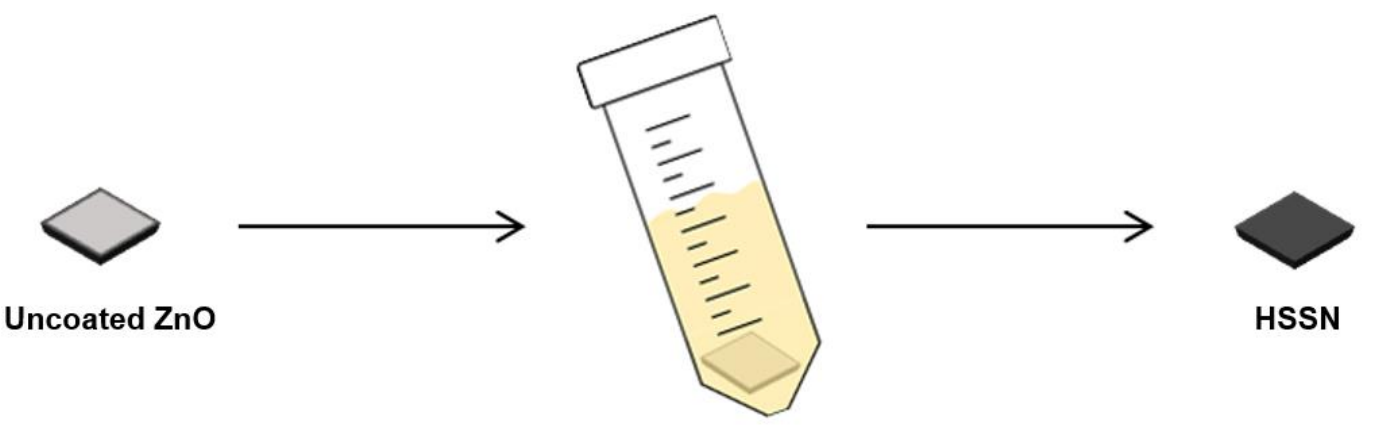

$\mathrm{TiO}_{2}$ coating
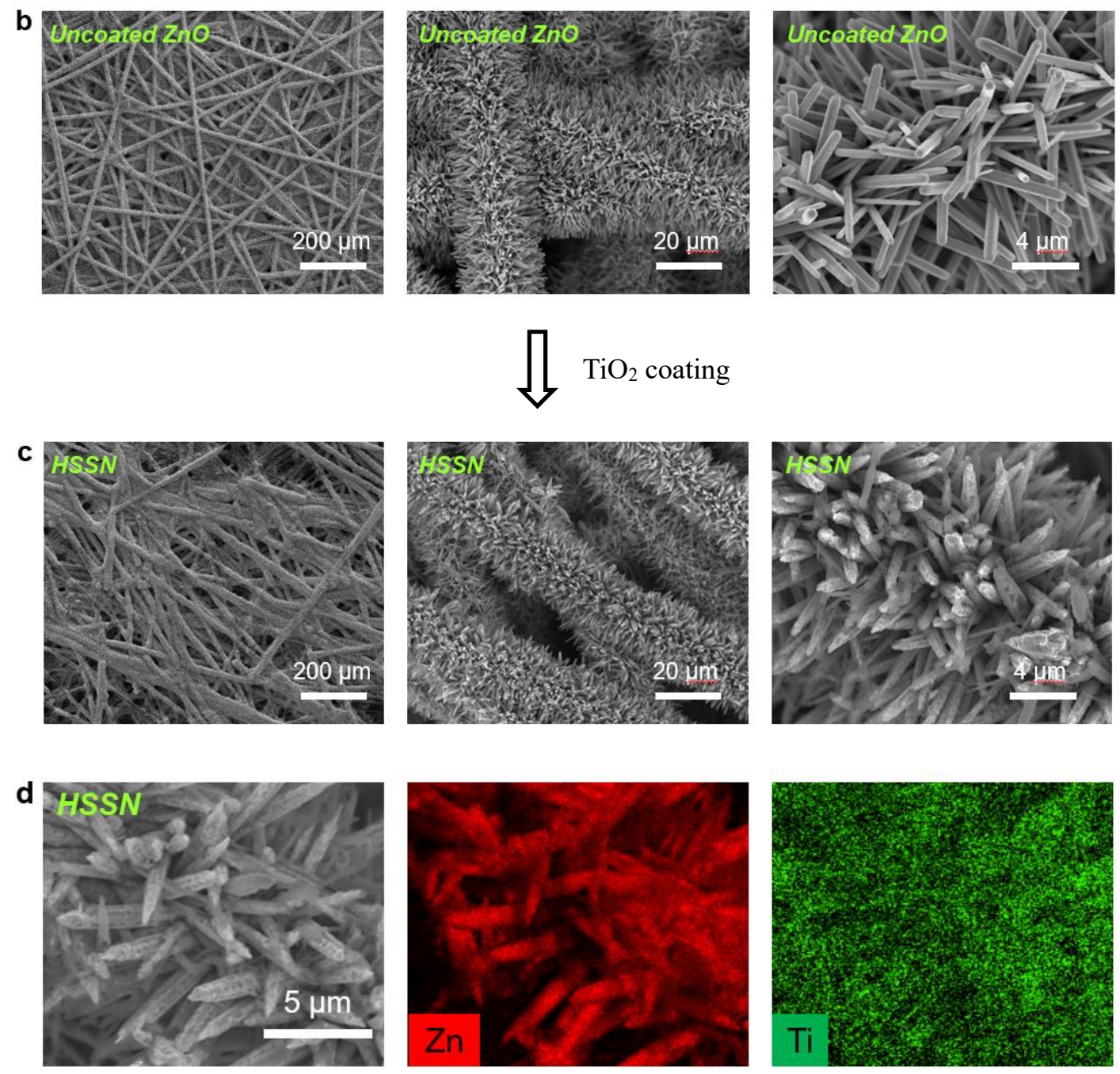

Figure S5. (a) Schematic diagram of $\mathrm{TiO}_{2}$ coating process. (b)(c) SEM images of $\mathrm{ZnO}$ nanorods before (b) and after $\mathrm{TiO}_{2}$ coating (c). (d) SEM image and elemental mappings of the HSSN anode. 

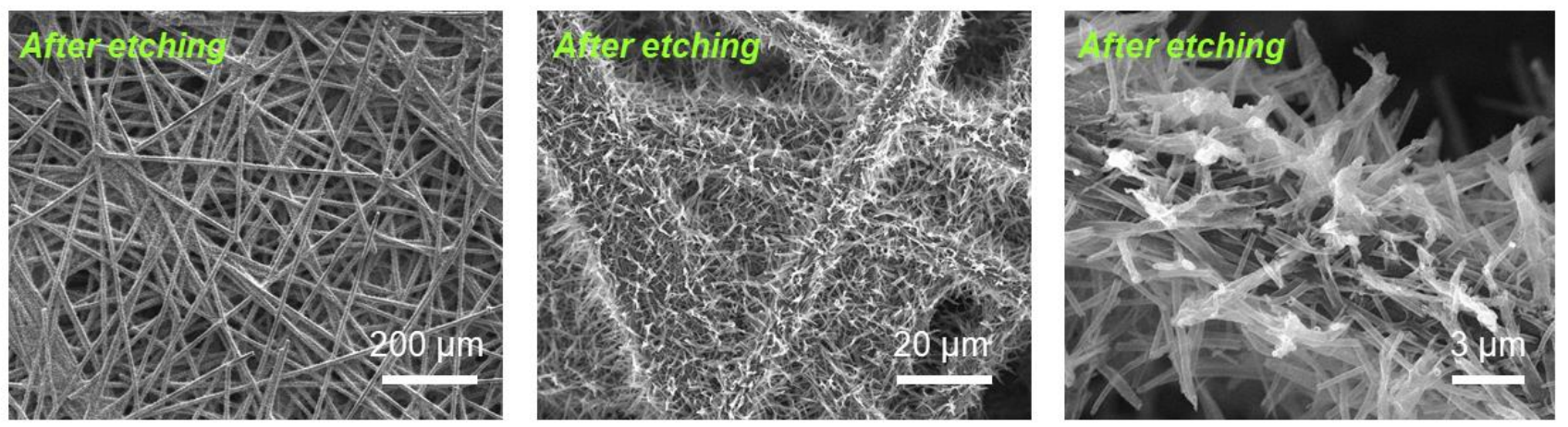

Figure S6. SEM images of HSSN anode after etching $\mathrm{ZnO}$ away. 
a Uncoated $\mathrm{ZnO}$ after soaking in $4 \mathrm{M} \mathrm{KOH}$
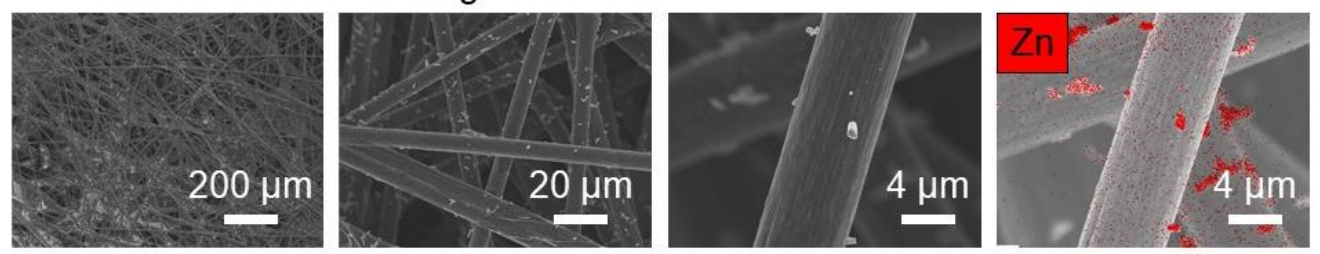

b HSSN after soaking in $4 \mathrm{M} \mathrm{KOH}$
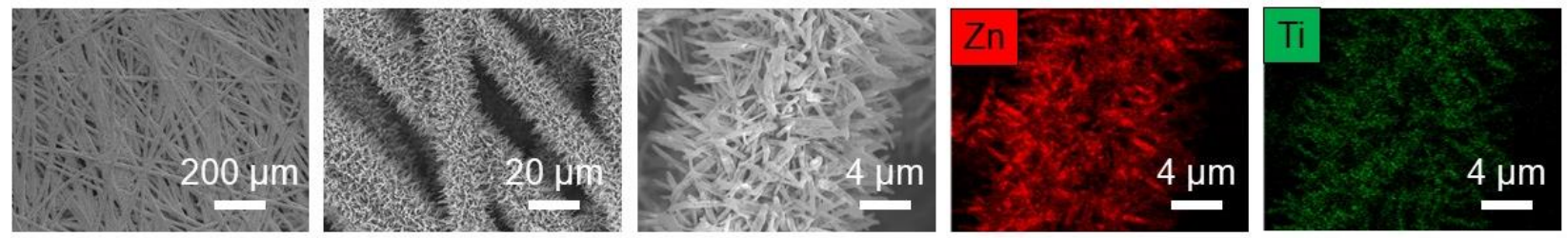

Figure S7. SEM images and elemental mappings of the uncoated $\mathrm{ZnO}$ (a) and HSSN (b) anodes after soaking in $4 \mathrm{M} \mathrm{KOH}$ solution. The reservation of $\mathrm{Zn}$ in the $\mathrm{HSSN}$ anode supports that $\mathrm{TiO}_{2}$ coating can effectively block zincate ions. 
a Uncoated ZnO anode after 5 cycles
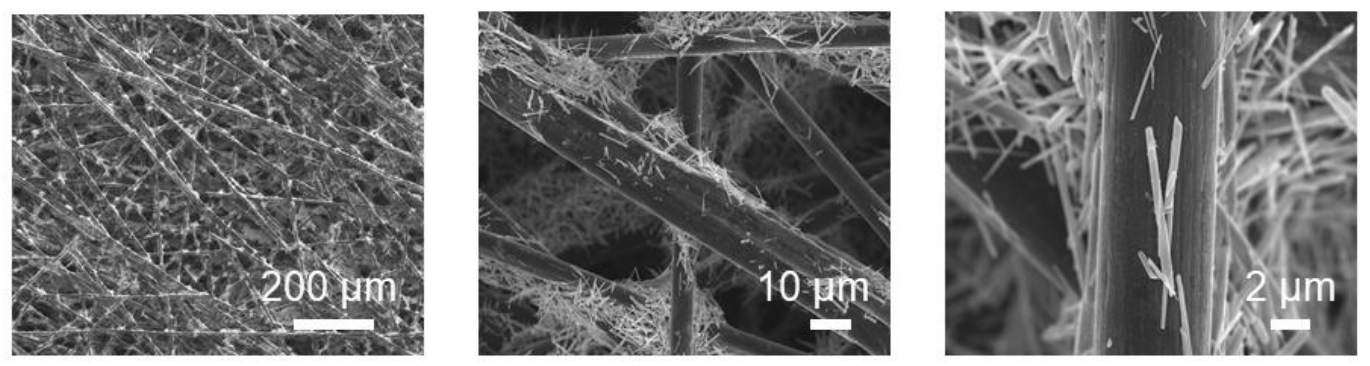

b HSSN anode after 5 cycles
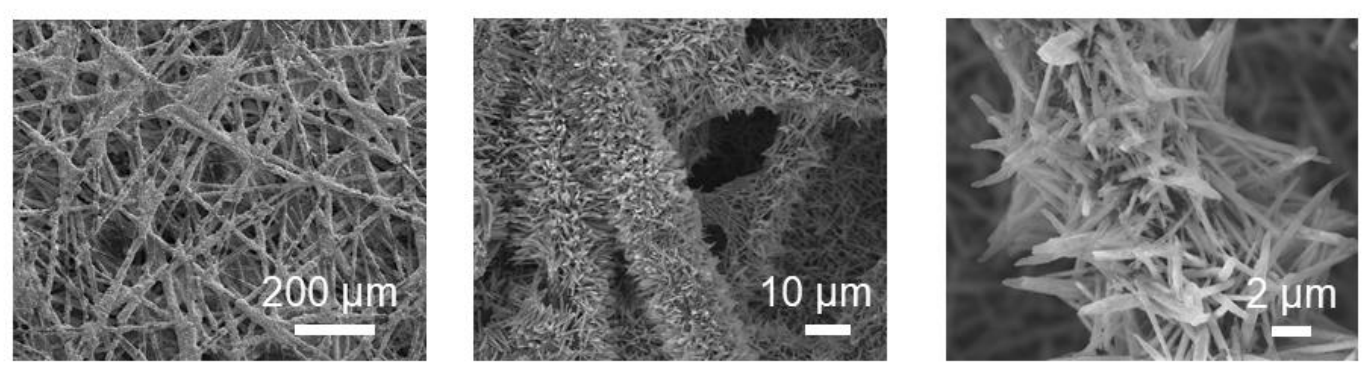

Figure S8. SEM images of uncoated $\mathrm{ZnO}$ nanorod anode (a) and HSSN anode (b) after five galvanostatic cycles with $25 \mu \mathrm{L}$ electrolyte. They were cycled at $0.25 \mathrm{~mA} / \mathrm{cm}^{2}$ for $2 \mathrm{~h}$ charge and $0.25 \mathrm{~mA} / \mathrm{cm}^{2}$ discharge to $1.5 \mathrm{~V}$. The mass loadings of $\mathrm{ZnO}$ nanorods on both anodes are $\sim 3.3 \mathrm{mg} / \mathrm{cm}^{2}$. 

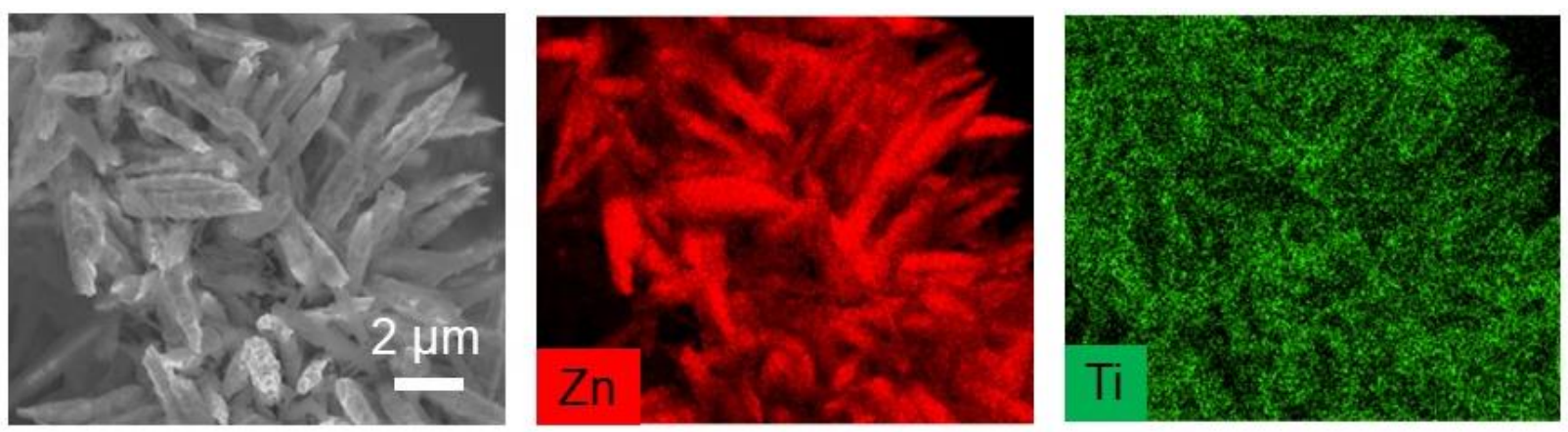

Figure S9. SEM image and elemental mappings of the HSSN anode after charge. 

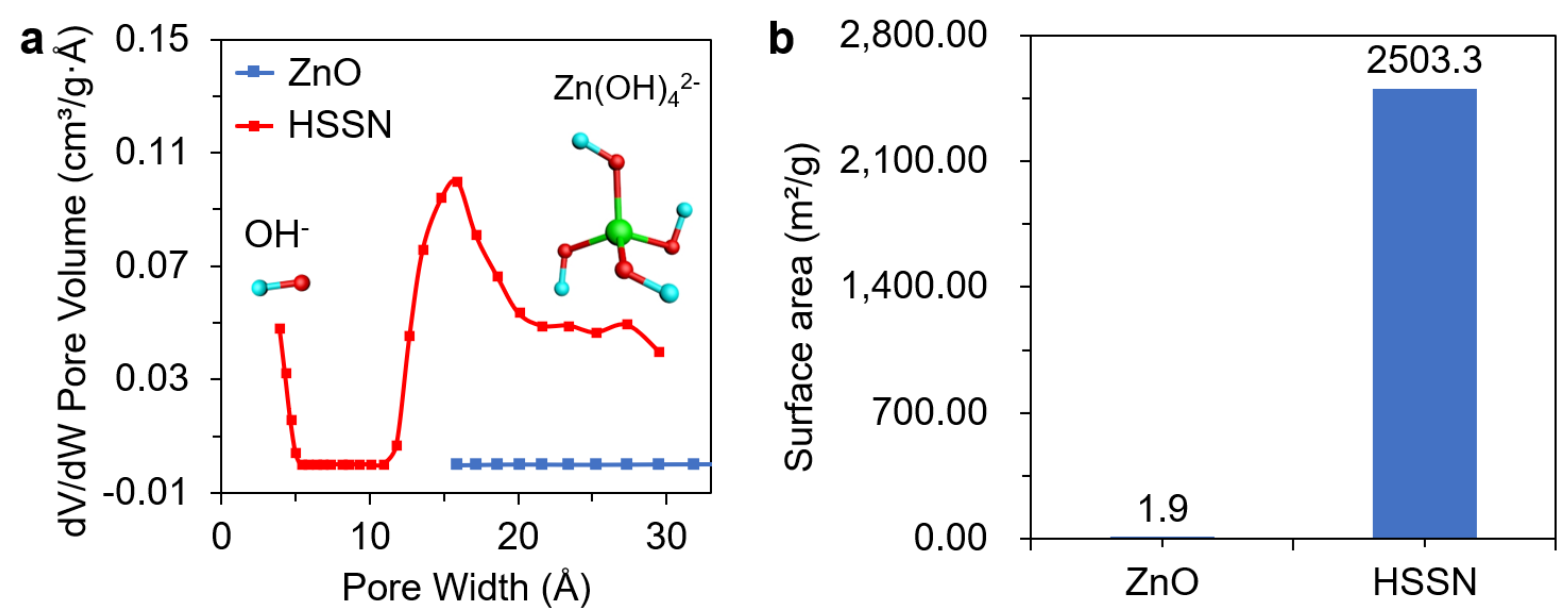

Figure S10. BET pore width distribution (a) and surface areas (b) of uncoated ZnO and HSSN anodes. After $\mathrm{TiO}_{2}$ coating, nanopores are measured, which indicates that $\mathrm{TiO}_{2}$ coating is nanoporous. 


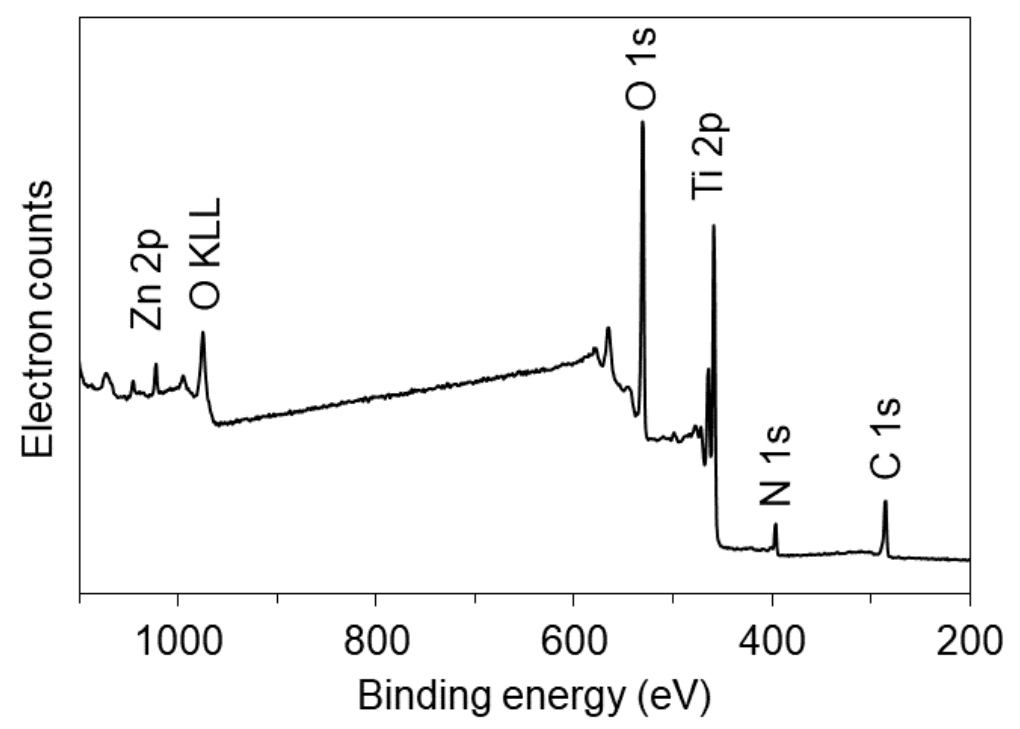

Figure S11. XPS survey spectra of the $\mathrm{ZnO} @ \mathrm{TiN}_{\mathrm{x}} \mathrm{O}_{\mathrm{y}}$ anode. The atomic ratio of $\mathrm{O}$ to $\mathrm{N}$ is $\sim 6.66$ in the $\mathrm{TiN}_{\mathrm{x}} \mathrm{O}_{\mathrm{y}}$ coating. 


\section{a $\mathrm{CP}-\mathrm{TiN}_{\mathrm{x}} \mathrm{O}_{\mathrm{y}}$}
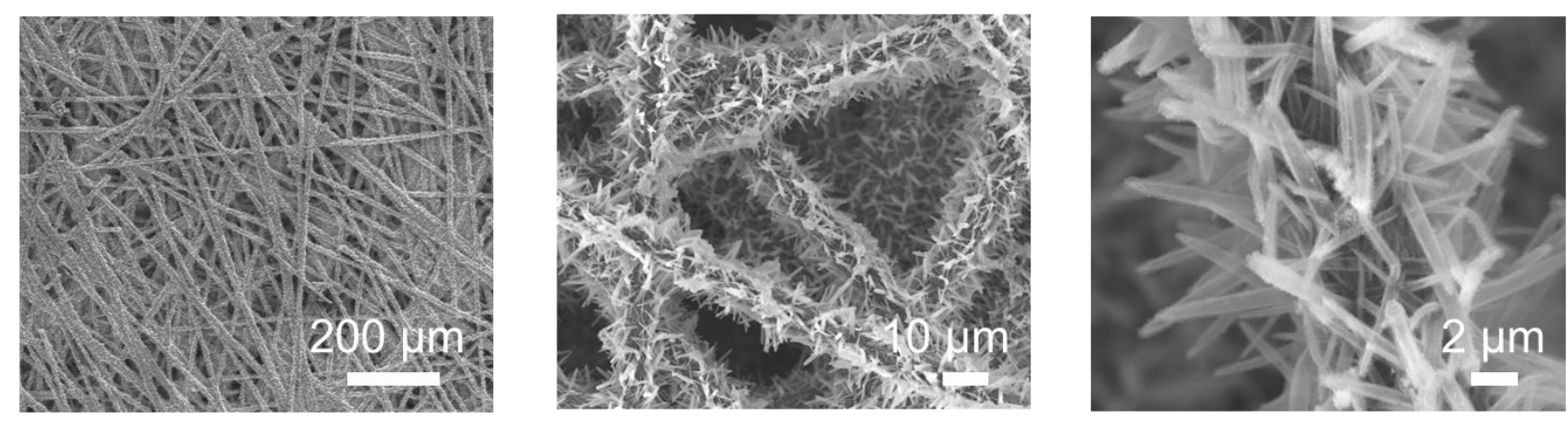

\section{b $\mathrm{CP}-\mathrm{TiO}_{2}$}

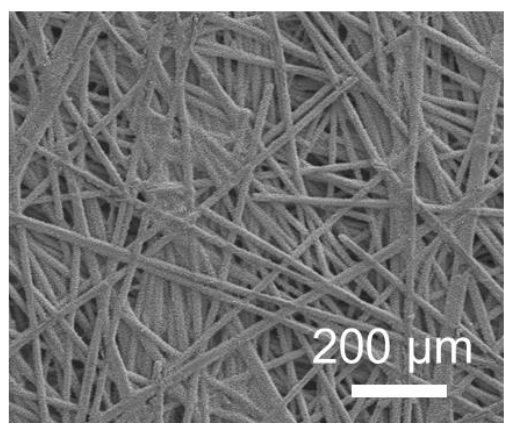

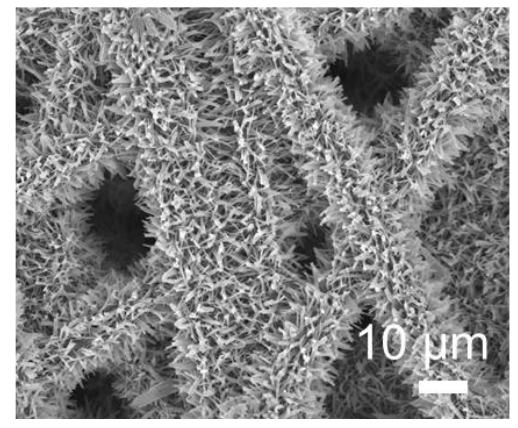

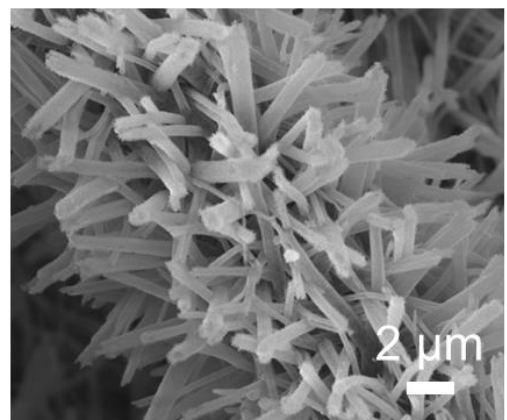

Figure S12. SEM images of $\mathrm{TiN}_{\mathrm{x}} \mathrm{O}_{\mathrm{y}}$ (a) and $\mathrm{TiO}_{2}$ (b) hollow nanorod coatings on CP substrates, which are prepared by etching away $\mathrm{ZnO}$ from the $\mathrm{HSSN}$ and $\mathrm{ZnO} @ \mathrm{TiN}_{\mathrm{x}} \mathrm{O}_{\mathrm{y}}$ anodes. 


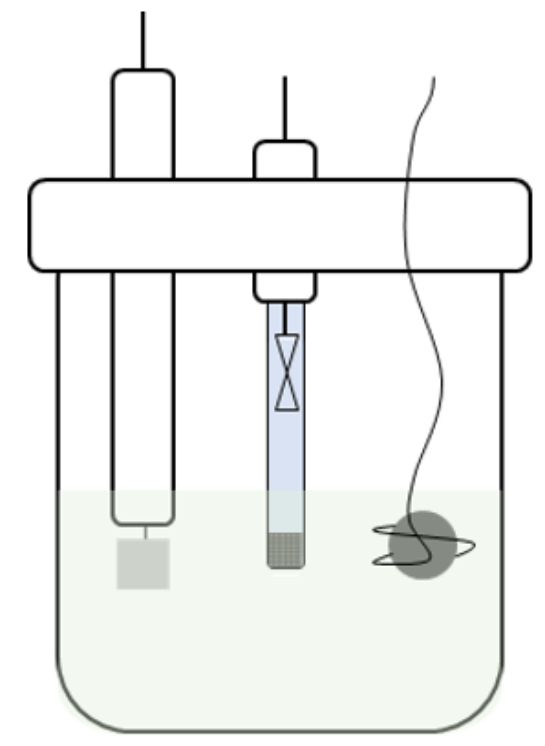

Figure S13. Schematic diagram of the three-electrode cell in $4 \mathrm{M} \mathrm{KOH}$ electrolyte with $\mathrm{TiO}_{2}$ or $\mathrm{TiN}_{\mathrm{x}} \mathrm{O}_{\mathrm{y}}$ electrode as the working electrode, $\mathrm{Hg} / \mathrm{HgO}$ electrode as the reference electrode, and $\mathrm{Pt}$ foil as the counter electrode. 


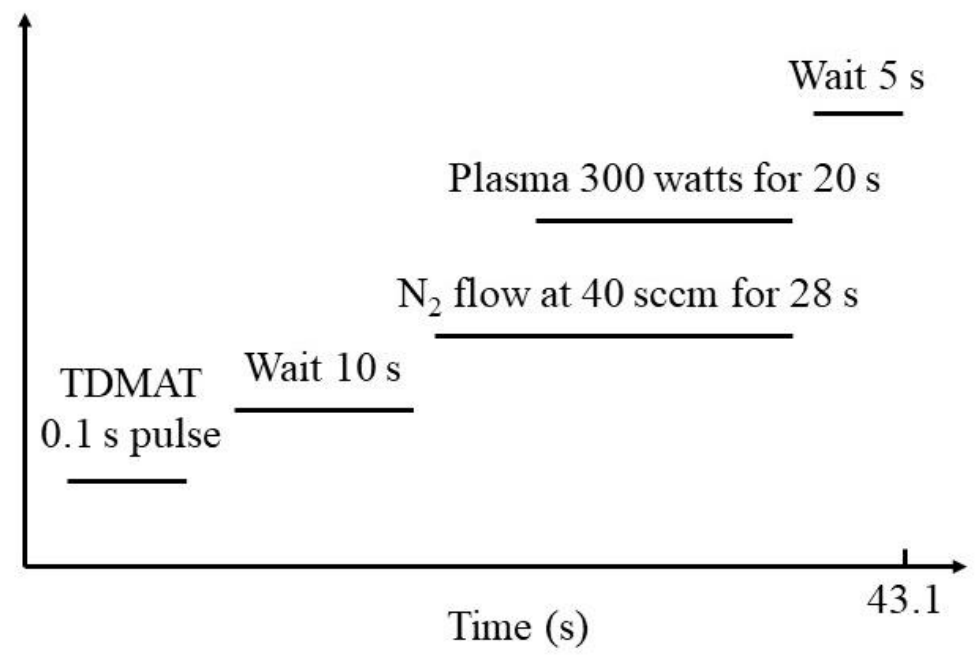

Figure S14. Schematic of TiN ALD recipe. 


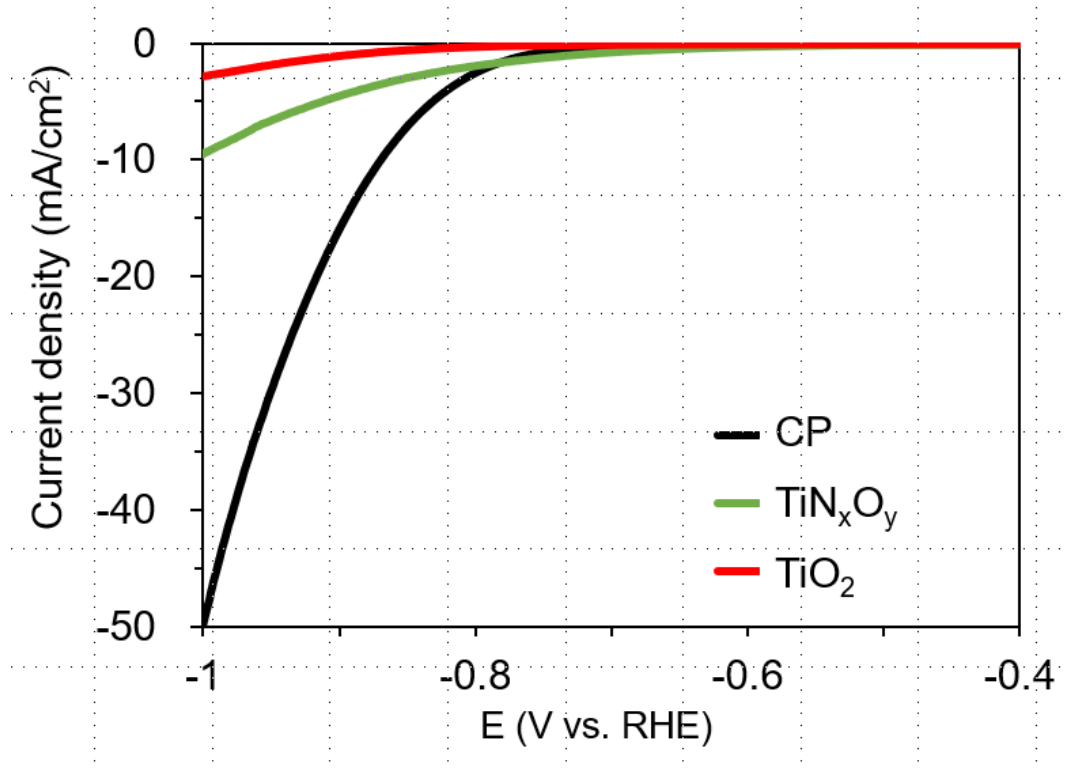

Figure S15. IR-corrected polarization curves of CP substrate, $\mathrm{TiN}_{\mathrm{x}} \mathrm{O}_{\mathrm{y}}$ and $\mathrm{TiO}_{2}$ electrodes. HER can be suppressed with the existence of $\mathrm{TiO}_{2}$. $\mathrm{CP}$ : carbon paper. Scan rate: $2 \mathrm{mV} / \mathrm{s}$. 

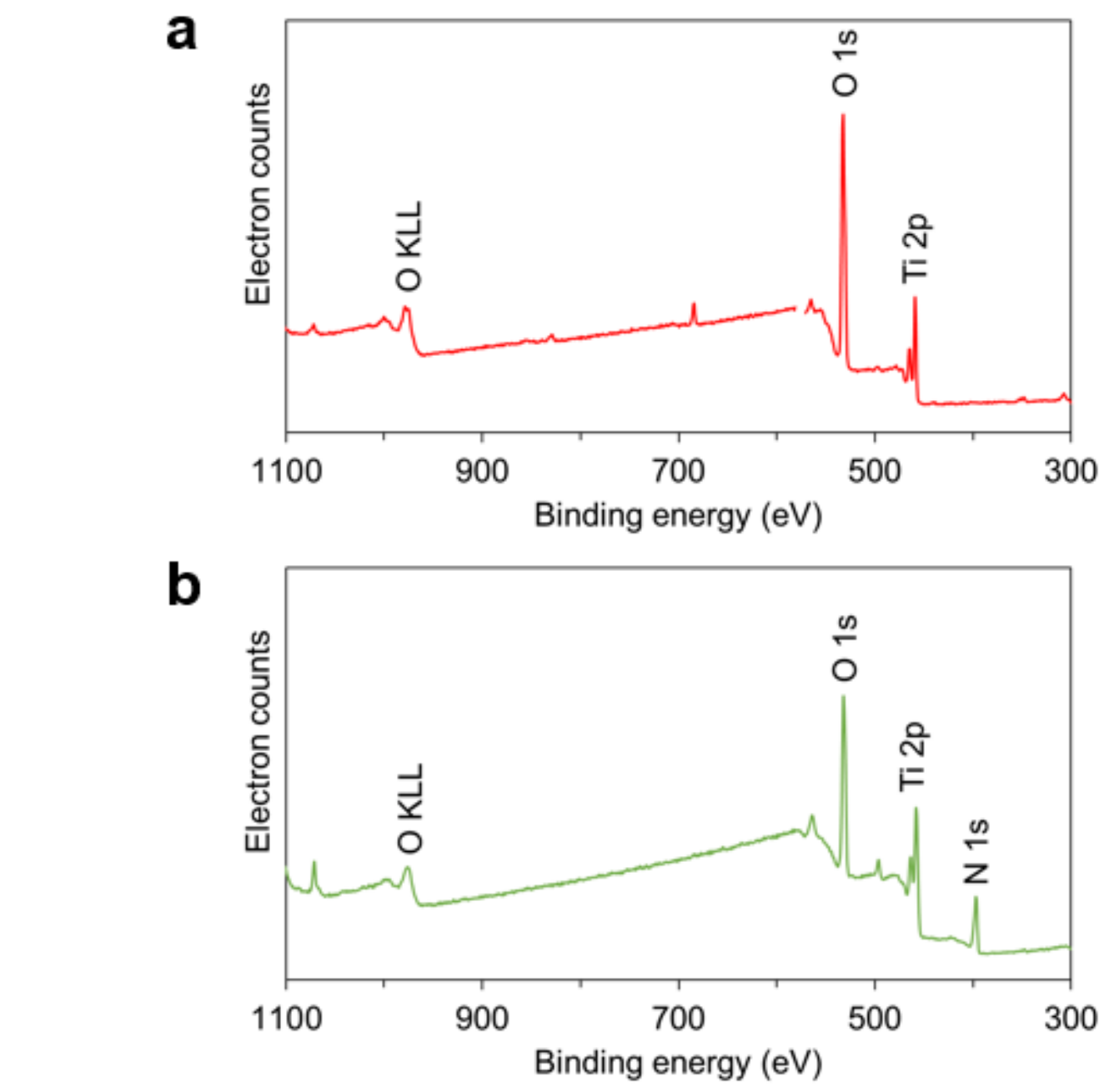

C

\section{Sheet resistance ( $\mathbf{\Omega} / \mathrm{sq}$.$) \quad Resistivity (\boldsymbol{\mu} \mathbf{\Omega} \cdot \mathrm{cm})$}

$\mathrm{TiN}_{\mathrm{x}} \mathrm{O}_{\mathrm{y}}$

$\mathrm{TiO}_{2}$
466.85

$\infty$
1867

$\infty$

Figure S16. (a) XPS survey spectra of the $\mathrm{TiO}_{2}$ coating. (b) XPS survey spectra of the $\mathrm{TiN}_{\mathrm{x}} \mathrm{O}_{\mathrm{y}}$ coating. (c) Sheet resistance and resistivity of $\mathrm{TiN}_{\mathrm{x}} \mathrm{O}_{\mathrm{y}}$ and $\mathrm{TiO}_{2}$ coatings measured using a four-point probe system. 

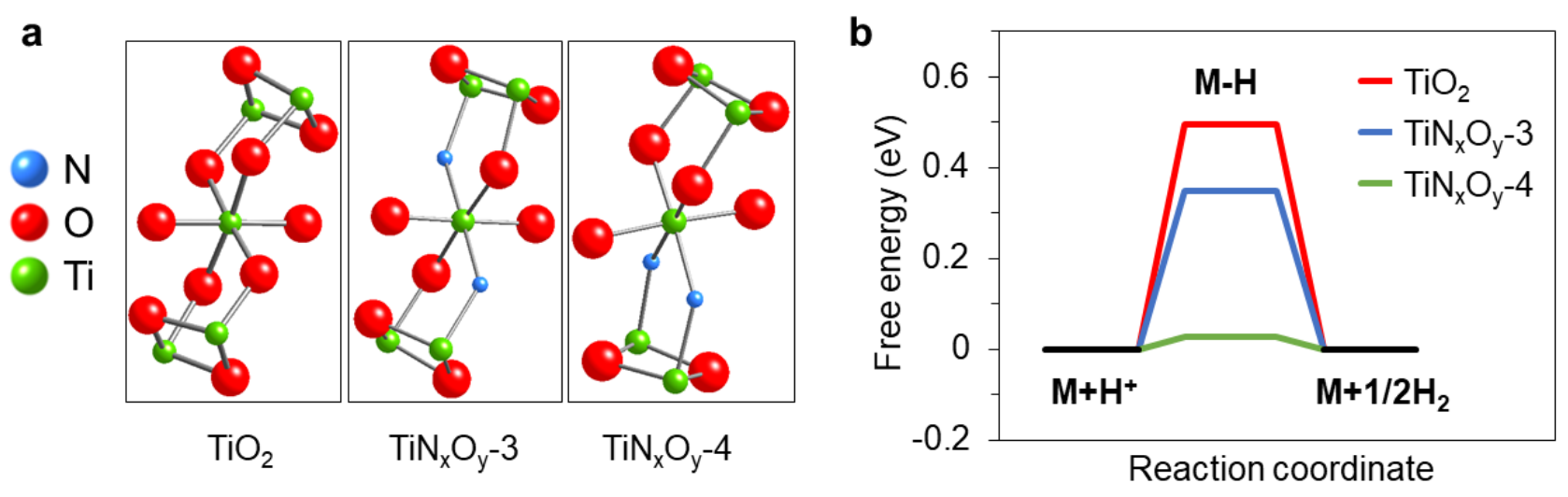

Figure S17. Basic models (a) and adsorption free energy diagram (b) of $\mathrm{TiO}_{2}, \mathrm{TiN}_{\mathrm{x}} \mathrm{O}_{\mathrm{y}}-3$ and $\mathrm{TiN}_{\mathrm{x}} \mathrm{O}_{\mathrm{y}}-4$ clusters. 


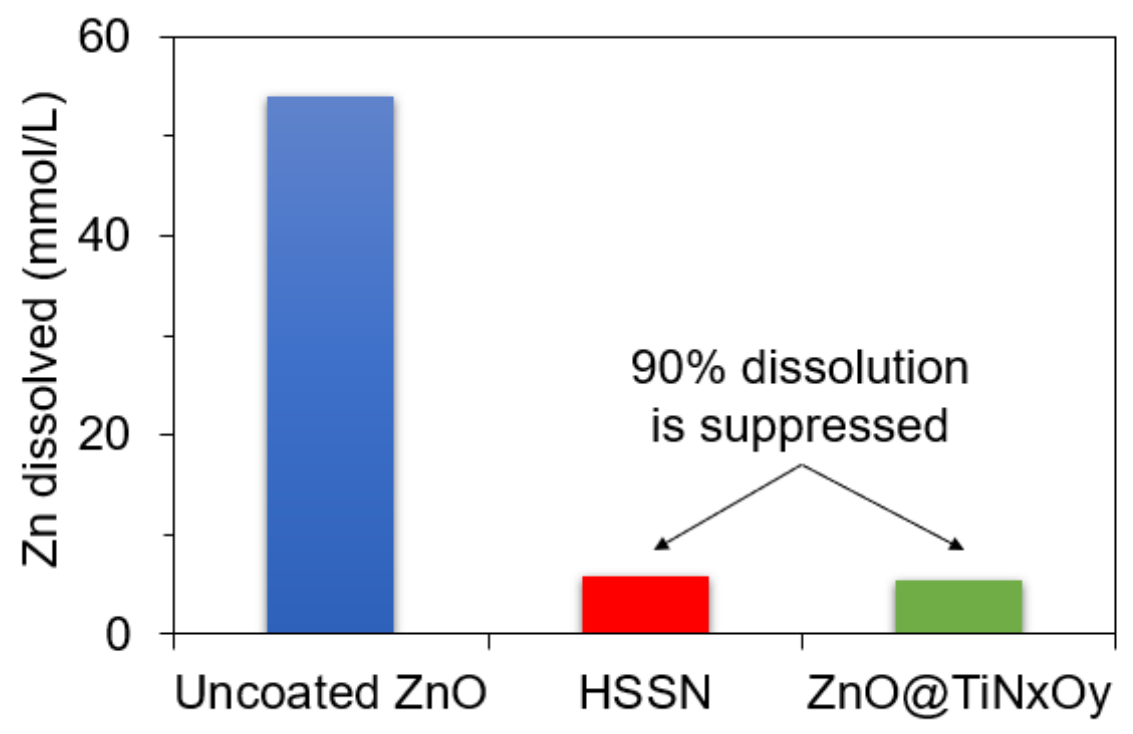

Figure S18. ICP results showing dissolved $\mathrm{Zn}$ concentration after soaking the uncoated $\mathrm{ZnO}, \mathrm{HSSN}$ and $\mathrm{ZnO} @ \mathrm{TiN}_{\mathrm{x}} \mathrm{O}_{\mathrm{y}}$ anodes in 4M KOH solution. 90\% $\mathrm{ZnO}$ dissolution is suppressed in the HSSN and $\mathrm{ZnO} @ \mathrm{TiN}_{\mathrm{x}} \mathrm{O}_{\mathrm{y}}$ anodes. HSSN and $\mathrm{ZnO} @ \mathrm{TiN}_{\mathrm{x}} \mathrm{O}_{\mathrm{y}}$ anodes have very similar ion-sieving capability. 
ZnO@TiN $\mathrm{O}_{\mathrm{y}}$ after soaking in $4 \mathrm{M} \mathrm{KOH}$ for $2 \mathrm{~h}$
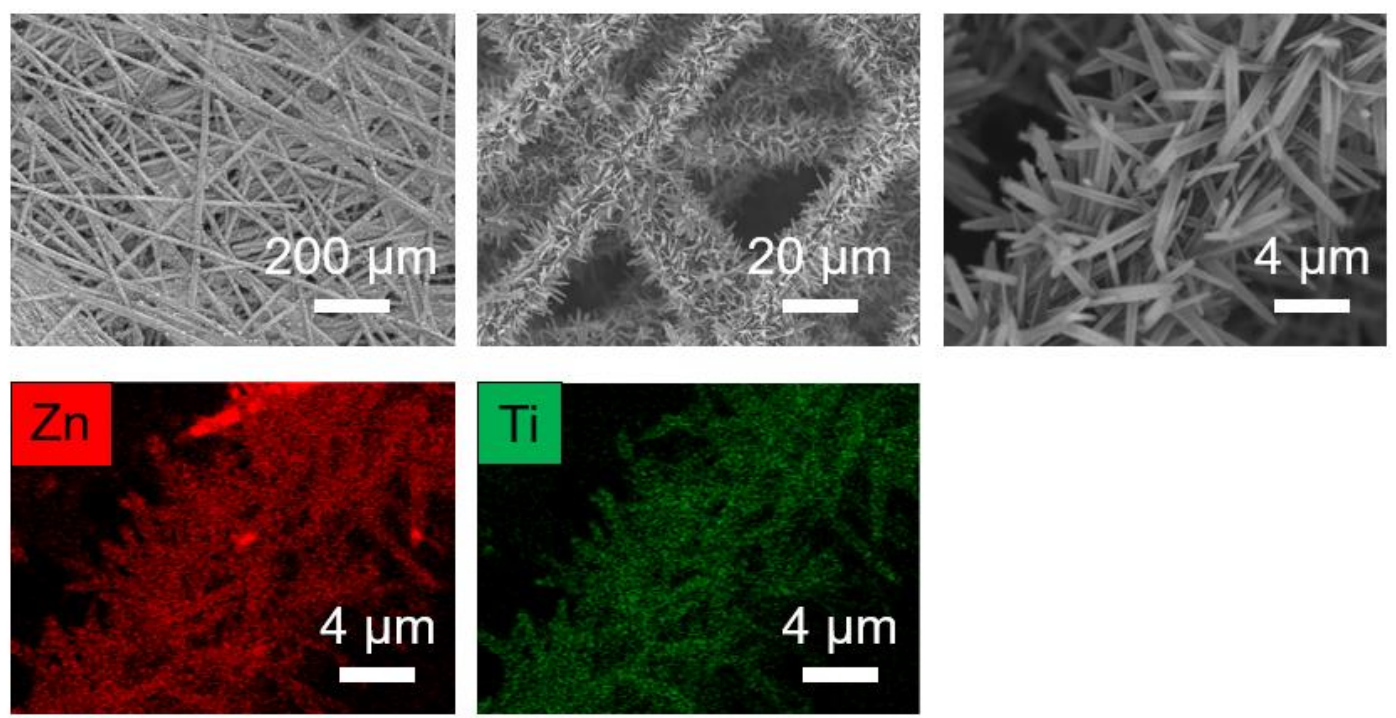

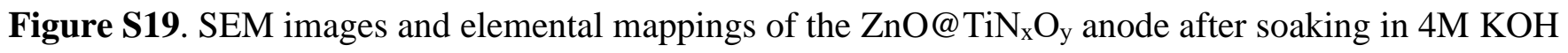
solution. The reservation of $\mathrm{Zn}$ in the $\mathrm{ZnO} @ \mathrm{TiN}_{\mathrm{x}} \mathrm{O}_{\mathrm{y}}$ anode supports that $\mathrm{TiN}_{\mathrm{x}} \mathrm{O}_{\mathrm{y}}$ coating can effectively block zincate ions. 

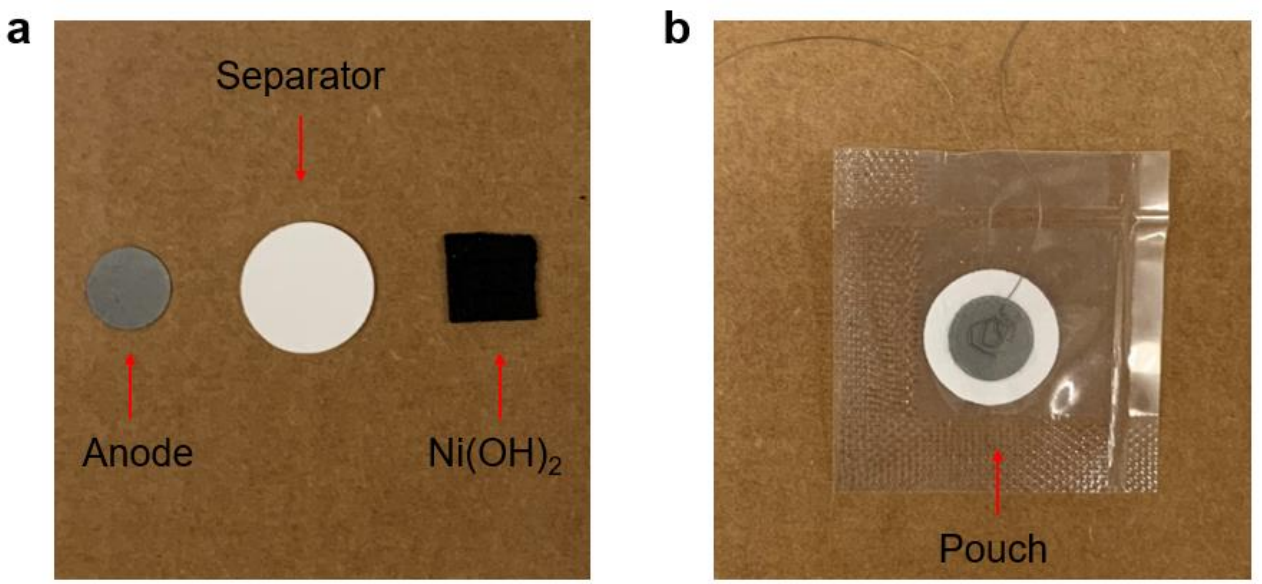

Figure S20. The cell components (a) and assembled pouch cell (b). Separator has $1.5 \mathrm{~cm}$ diameter. The anode has $1 \mathrm{~cm}$ diameter. 


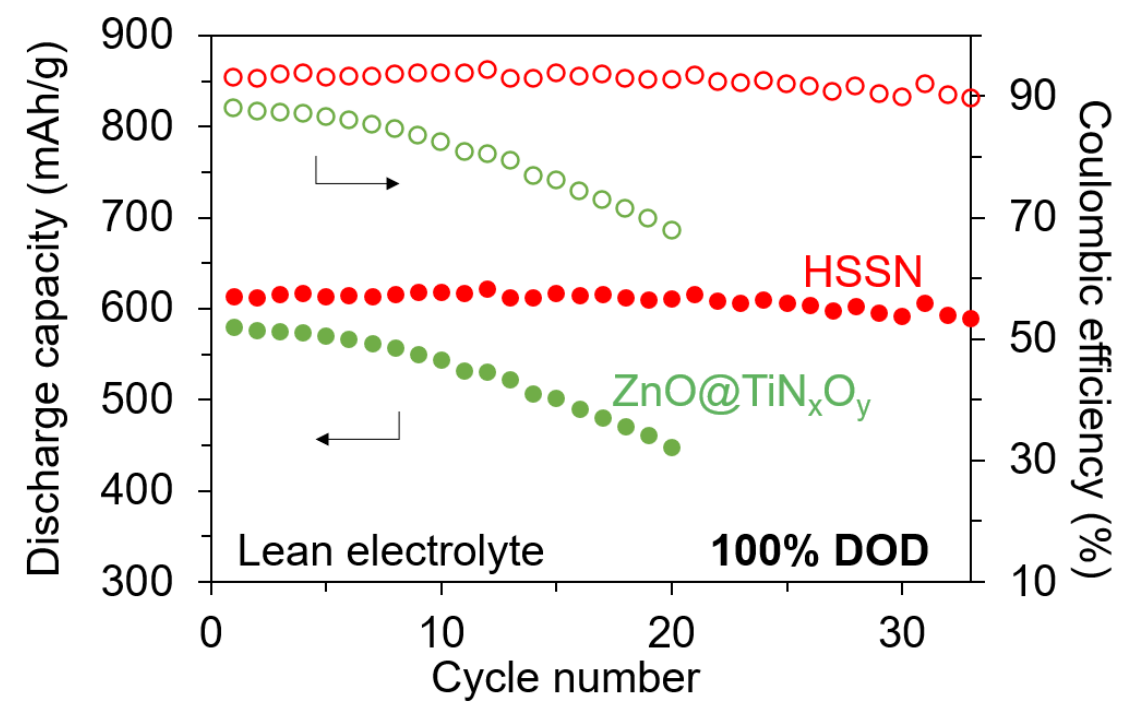

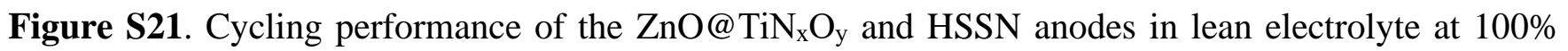
DOD. 


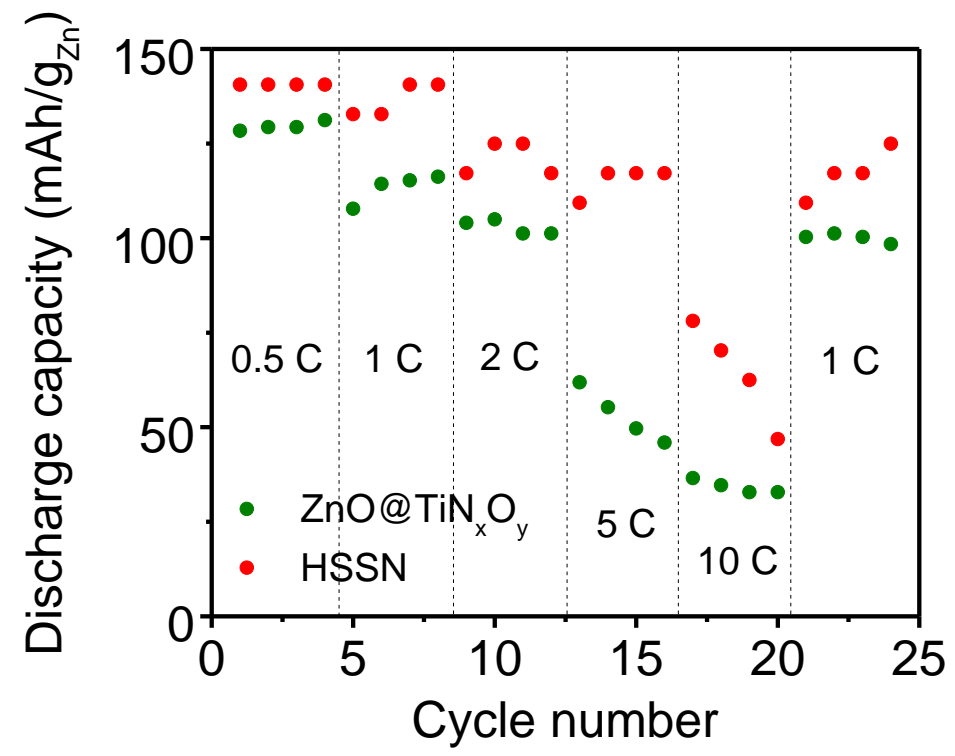

Figure S22. Cycling performance of the HSSN and $\mathrm{ZnO} @ \mathrm{TiN}_{\mathrm{x}} \mathrm{O}_{\mathrm{y}}$ anodes at various $\mathrm{C}$ rates. State of charge: $20 \%$. 

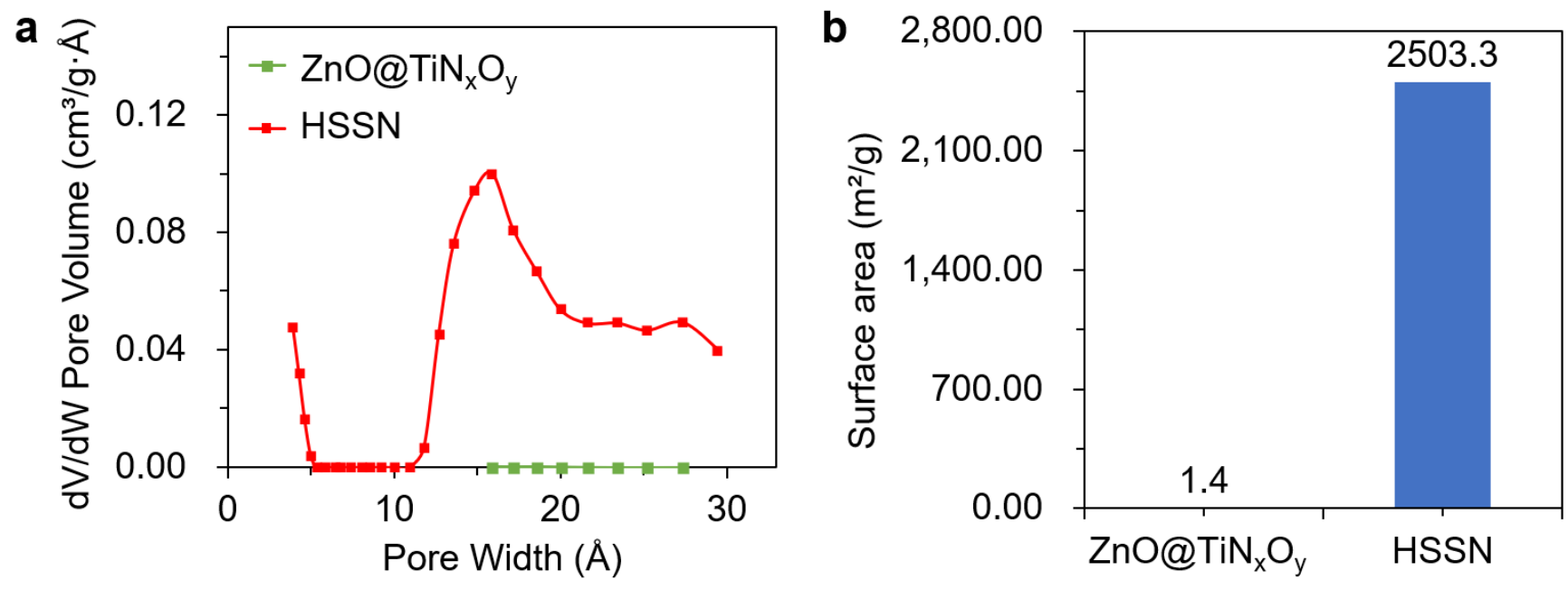

Figure S23. BET pore width distribution (a) and surface areas (b) of HSSN and ZnO@ $\mathrm{TiN}_{\mathrm{x}} \mathrm{O}_{\mathrm{y}}$ anodes. 


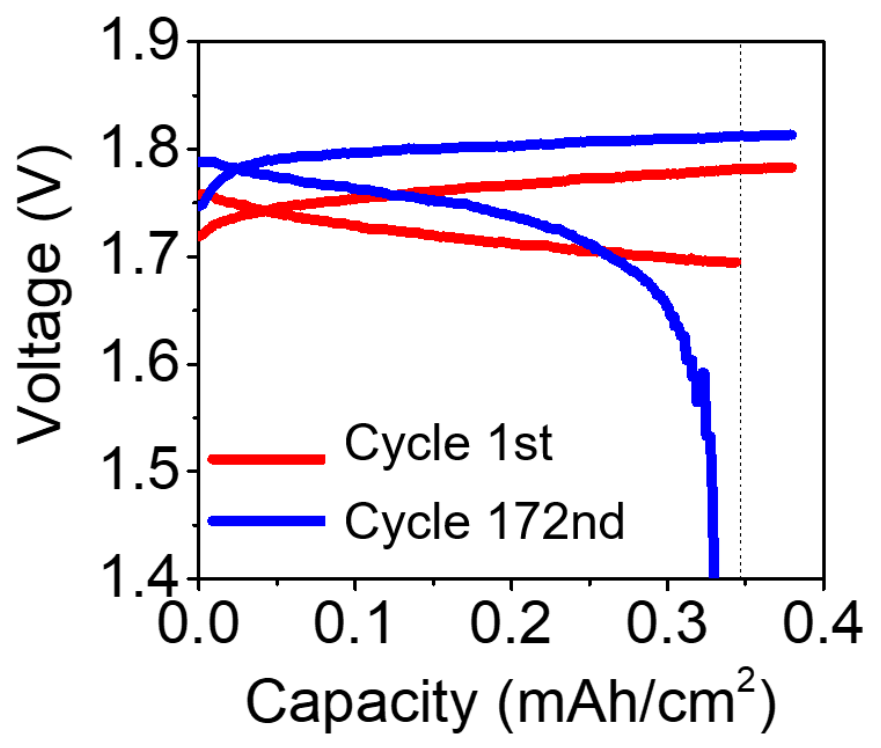

Figure S24. Charge-discharge profiles of the HSSN anode in lean electrolyte at 40\% DOD. 


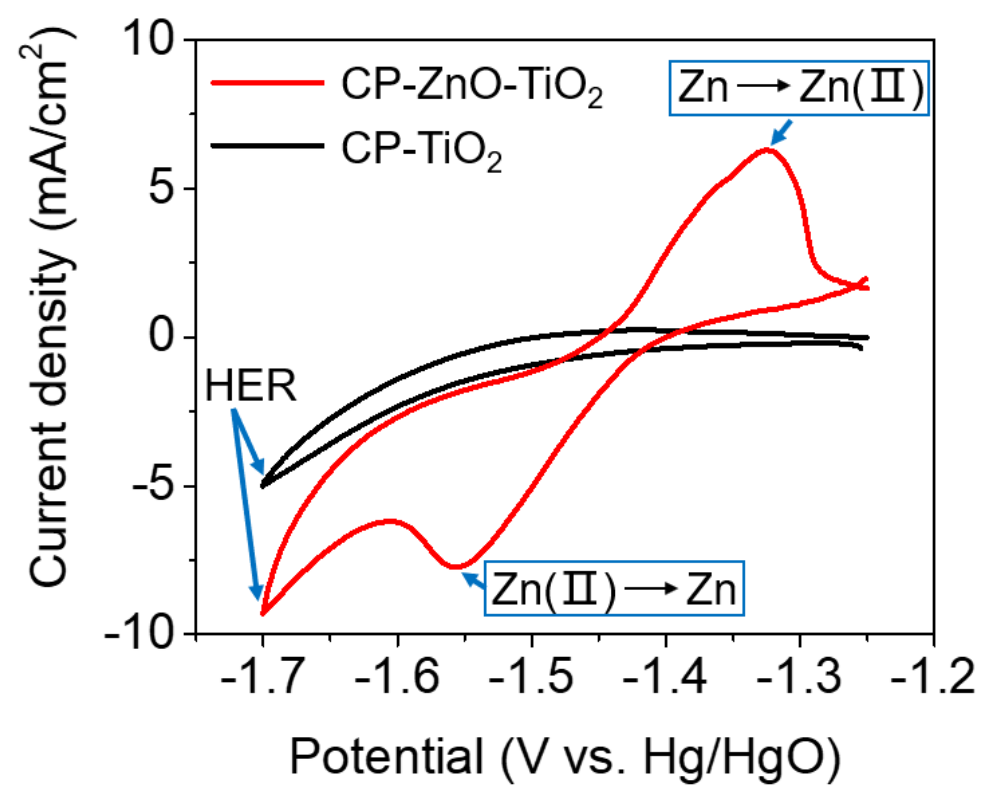

Figure S25. CV curves of $\mathrm{CP}-\mathrm{TiO}_{2}$ and $\mathrm{HSSN}$ electrodes. There is no capacity contribution from $\mathrm{TiO}_{2}$ during the electrochemical reaction. Scan rate: $10 \mathrm{mV} / \mathrm{s}$. 

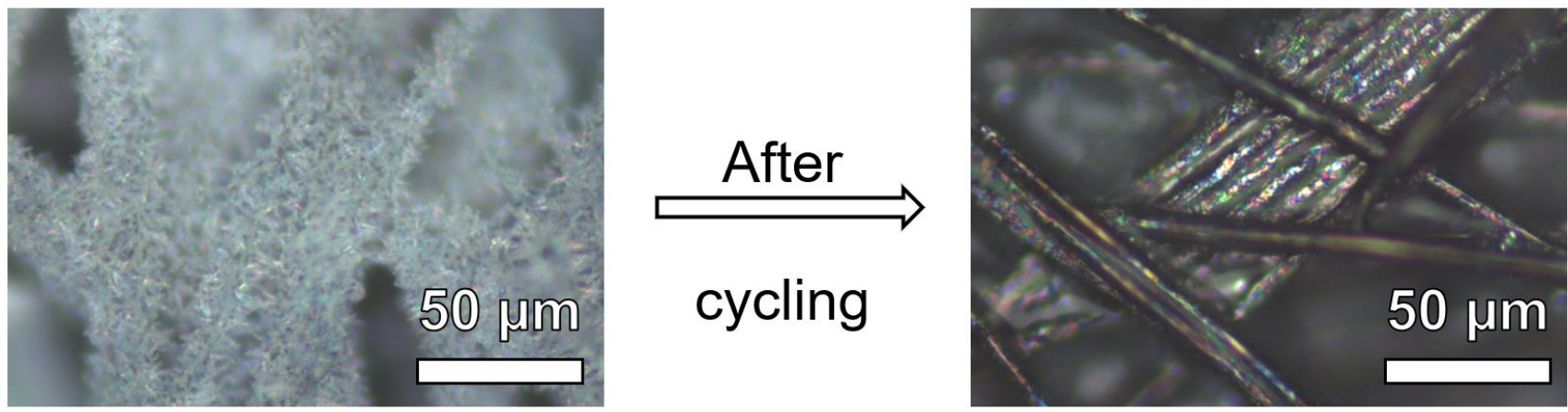

Figure S26. Optic microscope images of the HSSN anode before and after battery failure. 

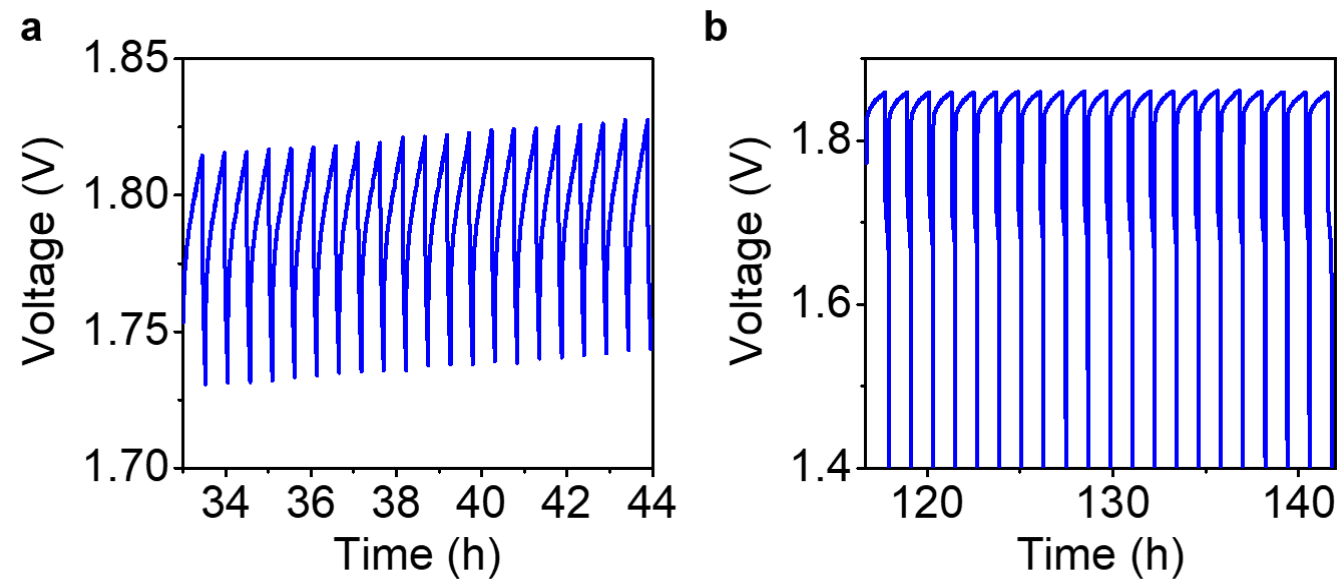

Figure S27. Voltage profiles (from cycle 50th to 70th) of the HSSN anode cycled in lean electrolyte at $40 \%$ DOD (a) and a beaker cell with a large amount of electrolyte at 100\% DOD (b). 


\section{References}

(1) Wang, J.; Zhong, H.; Wang, Z.; Meng, F.; Zhang, X. Integrated Three-Dimensional Carbon Paper/Carbon Tubes/Cobalt-Sulfide Sheets as an Efficient Electrode for Overall Water Splitting. ACS Nano 2016, 10 (2), $2342-2348$.

(2) Xu, C.; Wu, J.; Desai, U. V.; Gao, D. High-Efficiency Solid-State Dye-Sensitized Solar Cells Based on TiO 2 -Coated ZnO Nanowire Arrays. Nano Lett. 2012, 12 (5), 2420-2424.

(3) Parker, J. F.; Pala, I. R.; Chervin, C. N.; Long, J. W.; Rolison, D. R. Minimizing Shape Change at Zn Sponge Anodes in Rechargeable Ni-Zn Cells: Impact of Electrolyte Formulation. J. Electrochem. Soc. 2016, 163 (3), A351-A355.

(4) Nørskov, J. K.; Bligaard, T.; Logadottir, A.; Kitchin, J. R.; Chen, J. G.; Pandelov, S.; Stimming, U. Trends in the Exchange Current for Hydrogen Evolution. J. Electrochem. Soc. 2005, 152 (3), J23.

(5) Zheng, Y.; Jiao, Y.; Zhu, Y.; Li, L. H.; Han, Y.; Chen, Y.; Du, A.; Jaroniec, M.; Qiao, S. Z. Hydrogen Evolution by a Metal-Free Electrocatalyst. Nat. Commun. 2014, 5, 3783.

(6) Yuan, Y. F.; Tu, J. P.; Wu, H. M.; Li, Y.; Shi, D. Q.; Zhao, X. B. Effect of ZnO Nanomaterials Associated with Ca(OH) 2 as Anode Material for Ni-Zn Batteries. J. Power Sources 2006, 159 (1 SPEC. ISS.), 357-360.

(7) Yuan, Y. F.; Tu, J. P.; Wu, H. M.; Zhang, B.; Huang, X. H.; Zhao, X. B. Preparation, Characteristics and Electrochemical Performance of $\mathrm{Sn}_{6} \mathrm{O}_{4}(\mathrm{OH})_{4}$-Coated $\mathrm{ZnO}$ for $\mathrm{Zn}-\mathrm{Ni}$ Secondary Battery. Electrochem. commun. 2006, $8(4), 653-657$.

(8) Ma, M.; Tu, J. P.; Yuan, Y. F.; Wang, X. L.; Li, K. F.; Mao, F.; Zeng, Z. Y. Electrochemical Performance of ZnO Nanoplates as Anode Materials for Ni/Zn Secondary Batteries. J. Power Sources 2008, 179 (1), 395-400.

(9) Wu, J. Z.; Tu, J. P.; Yuan, Y. F.; Ma, M.; Wang, X. L.; Zhang, L.; Li, R. L.; Zhang, J. Ag-Modification Improving the Electrochemical Performance of ZnO Anode for Ni/Zn Secondary Batteries. J. Alloys Compd. 2009, 479 (1-2), 624628.

(10) Wang, L.; Liu, Y.; Chen, X.; Qin, H.; Yang, Z. Zinc Aluminum Antimony Hydrotalcite as Anode Materials for Ni-Zn Secondary Batteries. J. Electrochem. Soc. 2017, 164 (14), A3692-A3698.

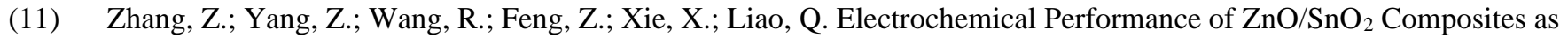
Anode Materials for Zn/Ni Secondary Batteries. Electrochim. Acta 2014, 134, 287-292.

(12) Sun, L.; Yi, Z.; Lin, J.; Liang, F.; Wu, Y.; Cao, Z.; Wang, L. Fast and Energy Efficient Synthesis of ZnO@ RGO and Its Application in Ni-Zn Secondary Battery. J. Phys. Chem. C 2016, 120 (23), 12337-12343.

(13) Wang, L.; Yang, Z.; Chen, X.; Qin, H.; Yan, P. Formation of Porous ZnO Microspheres and Its Application as Anode Material with Superior Cycle Stability in Zinc-Nickel Secondary Batteries. J. Power Sources 2018, 396 (April), 615620.

(14) Li, Z. Q.; Li, B. Q.; Qin, Z. X.; Lu, X. Fabrication of Porous Ag by Dealloying of Ag-Zn Alloys in $\mathrm{H}_{2} \mathrm{SO}_{4} \mathrm{Solution}_{\text {. J. }}$ Mater. Sci. 2010, 45 (23), 6494-6497.

(15) Liu, Y.; Yang, Z.; Xie, X.; Huang, J.; Wen, X. Layered Double Oxides Nano-Flakes Derived From Layered Double Hydroxides: Preparation, Properties and Application in Zinc/Nickel Secondary Batteries. Electrochim. Acta 2015, 185, $190-197$.

(16) Guo, W.; Yang, C.; Zhao, Z.; Xin, X.; Tian, Z.; Peng, K.; Lai, Y. MOFs Derived Ag/ZnO Nanocomposites Anode for Zn/Ni Batteries. J. Solid State Chem. 2019, 272, 27-31.

(17) Zeng, D.; Yang, Z.; Wang, S.; Ni, X.; Ai, D.; Zhang, Q. Preparation and Electrochemical Performance of In-Doped $\mathrm{ZnO}$ as Anode Material for Ni-Zn Secondary Cells. Electrochim. Acta 2011, 56 (11), 4075-4080.

(18) Guo, W.; Tian, Z; Yang, C.; Lai, Y.; Li, J. ZIF-8 Derived Nano-SnO $@$ ZnO as Anode for Zn/Ni Secondary Batteries. S38 
Electrochem. commun. 2017, 82 (June), 159-162.

(19) Yang, B.; Yang, Z.; Wang, R.; Feng, Z. Silver Nanoparticle Deposited Layered Double Hydroxide Nanosheets as a Novel and High-Performing Anode Material for Enhanced Ni-Zn Secondary Batteries. J. Mater. Chem. A 2014, 2 (3), 785-791.

(20) Parker, J. F.; Chervin, C. N.; Pala, I. R.; Machler, M.; Burz, M. F.; Long, J. W.; Rolison, D. R. Rechargeable Nickel3D Zinc Batteries: An Energy-Dense, Safer Alternative to Lithium-Ion. Science. 2017, 356 (6336), 415-418.

(21) Higashi, S.; Lee, S. W.; Lee, J. S.; Takechi, K.; Cui, Y. Avoiding Short Circuits from Zinc Metal Dendrites in Anode by Backside-Plating Configuration. Nat. Commun. 2016, 7 (1), 11801.

(22) Wu, Y.; Zhang, Y.; Ma, Y.; Howe, J. D.; Yang, H.; Chen, P.; Aluri, S.; Liu, N. Ion-Sieving Carbon Nanoshells for Deeply Rechargeable Zn-Based Aqueous Batteries. Adv. Energy Mater. 2018, 8 (36), 1802470.

(23) Zhang, Y.; Wu, Y.; Ding, H.; Yan, Y.; Zhou, Z.; Ding, Y.; Liu, N. Sealing ZnO Nanorods for Deeply Rechargeable High-Energy Aqueous Battery Anodes. Nano Energy 2018, 53, 666-674.

(24) Chen, P.; Wu, Y.; Zhang, Y.; Wu, T.-H.; Ma, Y.; Pelkowski, C.; Yang, H.; Zhang, Y.; Hu, X.; Liu, N. A Deeply Rechargeable Zinc Anode with Pomegranate-Inspired Nanostructure for High-Energy Aqueous Batteries. J. Mater. Chem. A 2018, 6 (44), 21933-21940.

(25) Yan, Y.; Zhang, Y.; Wu, Y.; Wang, Z.; Mathur, A.; Yang, H.; Chen, P.; Nair, S.; Liu, N. A Lasagna-Inspired Nanoscale ZnO Anode Design for High-Energy Rechargeable Aqueous Batteries. ACS Appl. Energy Mater. 2018, 1 (11), 63456351.

(26) Yuan, Y. F.; Tu, J. P.; Wu, H. M.; Li, Y.; Shi, D. Q. Size and Morphology Effects of ZnO Anode Nanomaterials for Zn/Ni Secondary Batteries. Nanotechnology 2005, 16 (6), 803-808.

(27) Zhang, C.; Wang, J. M.; Zhang, L.; Zhang, J. Q.; Cao, C. N. Study of the Performance of Secondary Alkaline Pasted Zinc Electrodes. J. Appl. Electrochem. 2001, 31 (9), 1049-1054.

(28) Michlik, T.; Schmid, M.; Rosin, A.; Gerdes, T.; Moos, R. Mechanical Coating of Zinc Particles with $\mathrm{Bi}_{2} \mathrm{O}_{3}-\mathrm{Li}_{2} \mathrm{O}-\mathrm{ZnO}$ Glasses as Anode Material for Rechargeable Zinc-Based Batteries. Batteries 2018, 4 (1), 12.

(29) Stock, D.; Dongmo, S.; Damtew, D.; Stumpp, M.; Konovalova, A.; Henkensmeier, D.; Schlettwein, D.; Schröder, D. Design Strategy for Zinc Anodes with Enhanced Utilization and Retention: Electrodeposited Zinc Oxide on Carbon Mesh Protected by Ionomeric Layers. ACS Appl. Energy Mater. 2018, 1 (10), acsaem.8b01117.

(30) Kim, J.; Im, Y.; Park, K. S.; Cho, T. W.; Jeon, J.; Chung, K.; Kang, M. Improved Cell Performances in Ni/Zn Redox Batteries Fabricated by ZnO Materials with Various Morphologies Synthesized Using Amine Chelates. J. Ind. Eng. Chem. 2017, 56, 463-471.

(31) Kang, S.; Im, Y.; Park, K. S.; Cho, T. W.; Jeon, J.; Chung, K.; Kang, M. The Incorporation of Cr Ions into the Framework of $\mathrm{ZnO}$ for Stable Electrochemical Performance in a Membrane Free Alkaline Ni/Zn Redox. Electrochim. Acta 2016, 209, 623-631.

(32) Im, Y.; Kim, K. M.; Park, K. S.; Cho, T. W.; Jeon, J.; Chung, K.; Kang, M. Inhibition of Zn Dendrite Growth Using $\mathrm{Ni}_{x} \mathrm{Zn}_{(1-\mathrm{x})} \mathrm{O}$ Anodic Material during a Redox Cycling Test in Zn/Ni Battery. Solid State Ionics 2016, 295, 13-24.

(33) Kwak, B. S.; Jo, S. W.; Park, K. S.; Cho, T. W.; Jeon, J.; Chung, K.; Kang, M. Synthesis of Microcrystalline ZnO as an Anodic Material via a Solvothermal Method, and Its Electrochemical Performance in Ni/Zn Redox Battery. J. Ind. Eng. Chem. 2017, 46, 111-118.

(34) Kwak, B. S.; Kim, D. Y.; Park, S. S.; Kim, B. S.; Kang, M. Implementation of Stable Electrochemical Performance Using a $\mathrm{Fe}_{0.01} \mathrm{ZnO}$ Anodic Material in Alkaline Ni-Zn Redox Battery. Chem. Eng. J. 2015, 281, 368-378.

(35) Im, Y.; Kang, S.; Kwak, B. S.; Park, K. S.; Cho, T. W.; Lee, J.-S.; Kang, M. Electrochemical Performance of Three S39 
Shaped $\mathrm{ZnO}$ Nanoparticles Prepared in $\mathrm{LiOH}, \mathrm{NaOH}$ and $\mathrm{KOH}$ Alkaline Solutions as Anodic Materials for Ni/Zn Redox Batteries. Korean J. Chem. Eng. 2016, 33 (4), 1447-1455.

(36) Im, Y.; Kim, J.; Park, K. S.; Cho, T. W.; Jeon, J.; Chung, K.; Eguchi, K.; Kang, M. Influence of Small Amount of Mg Incorporated into Hexagonal ZnO Crystal on Cell Performance in Membrane Free Zinc-Nickel Redox Battery. J. Ind. Eng. Chem. 2018, 64, 318-327. 